DOI: 10.32089/WBH.PHW.2020.3(273).0003

orcid.org/0000-0002-2991-8152

Mariusz Niestrawsi

(Muzeum Narodowe Rolnictwa i Przemysłu Rolno-Spożywczego w Szreniawie)

\title{
III Dywizjon Lotniczy w walce z 1 Armią Konną na przedpolach Lwowa (9-19 sierpnia 1920 roku)
}

\section{Wstęp}

Rok 1920 przyniósł co najmniej kilka spektakularnych akcji polskiego lotnictwa wojskowego. Na przełomie maja i czerwca V Dywizjon Lotniczy (DL) z powodzeniem zwalczał bolszewicką żeglugę na Dnieprze. Na Podolu $\mathrm{w}$ walkach $\mathrm{z}$ wrogimi pociągami pancernymi odznaczył się w tym czasie III DL. Ta sama jednostka wyróżniła się w sierpniu tego roku - przeprowadziła wówczas na przedpolach Lwowa szereg nalotów nękających przeciw 1 Armii Konnej Siemiona Budionnego.

Niniejszy artykuł ma na celu szczegółowe omówienie tego nieco zapomnianego epizodu $\mathrm{z}$ historii polskich Wojsk Lotniczych i wojny polsko-bolszewickiej. Narrację poprowadzono od 9 do 19 sierpnia $1920 \mathrm{r}$. Wykonany 9 sierpnia lot rozpoznawczy jednej z załóg III DL wykrył zbliżającą się nową ofensywę 1 Armii Konnej. W nocy 19/20 sierpnia natomiast dowodzony przez komandarma ${ }^{1}$ Siemiona Budionnego związek operacyjny zaprzestał prób zajęcia Lwowa, po czym odmaszerował w kierunku północno-wschodnim. Poza ramy artykułu wykracza natomiast omówienie drugiego etapu bitwy na przedpolach Lwowa, który to etap przypadł na trzecią dekadę sierpnia. Wówczas niebezpieczeństwo zajęcia stolicy Galicji groziło głównie

\footnotetext{
${ }^{1}$ W ówczesnej Armii Czerwonej tradycyjne stopnie oficerskie traktowano jako pozostałości znienawidzonych czasów carskich. Zamiast nich stosowano skróty nazw stanowisk służbowych. Pod pojęciem gławkom krył się głównodowodzący. Komandarm 1 rangi oznaczał dowódcę frontu, komandarm 2 rangi - dowódcę armii, komdyw - dowódcę dywizji, a kombrig dowódcę brygady. Z pewnym nadużyciem można byłoby stwierdzić, że komandarm odpowiadał rangą generałowi broni, komdyw - generałowi dywizji, a kombrig - generałowi brygady.
} 
ze strony bolszewickiej 14 Armii. Wątek ten został świadomie pominięty nie tylko ze względu na kluczową rolę 14 Armii, a nie 1 Armii Konnej, ale przede wszystkim z powodu nieproporcjonalnie mniejszego znaczenia polskiego lotnictwa w tym czasie. Omawiane wydarzenia toczyły się w Galicji Wschodniej, zasadniczo w trójkącie, którego dwoma wierzchołkami były Lwów i Kamionka Strumiłowa, a przeciwległy do lwowskiego wierzchołka bok stanowiła rzeka Bug (na odcinku od Kamionki Strumiłowej do Buska).

Akcje lotnicze zostały szczegółowo omówione w czterech ułożonych chronologicznie podrozdziałach. Zostały one poprzedzone przedstawieniem szeregu czynników istotnych z militarnego punktu widzenia, takich jak: teren, warunki atmosferyczne, siły i plany obu stron, a w szczególności - siły i taktyka polskiego lotnictwa.

Artykuł powstał głównie na podstawie szczegółowych wykazów lotów III DL w sierpniu 1920 r. Rzeczone materiały są przechowywane w zasobie Centralnego Archiwum Wojskowego Wojskowego Biura Historycznego. Kopie wymienionych dokumentów udostępnił salezjanin ks. Robert Kulczyński (Towarzystwo św. Franciszka Salezego; łac. Societas Sancti Francisci Salesii - SDB). Kilka meldunków lotniczych dywizjonu można ponadto odnaleźć w opracowanym przez zespół Marka Tarczyńskiego dwuczęściowym wydawnictwie źródłowym Bitwa lwowska i zamojska².

W przypadku tego tematu nie należy bagatelizować znaczenia artykułów o charakterze retrospektywnym. Już w 1922 r. na łamach „Bellony” wspomnienia z tej akcji opublikował ówczesny por. Tomasz Turbiak ${ }^{3}$. Na podstawie relacji zasłużonego lotnika 5 Eskadry Wywiadowczej (EW) trudno odtworzyć szczegółowy obraz działań dywizjonu, ale jest to kapitalne źródło dla poznania ówczesnej taktyki polskiego lotnictwa. Kilka lat po ukazaniu się artykułu Turbiaka na łamach „Przeglądu Lotniczego” wypowiedział się inny weteran walk - mjr/ppłk pil. Edward Lewandowski ${ }^{4}$. Były pilot 15 Eskadry Myśliwskiej (EM) podjął między innymi zagadnienia dotyczące personelu i sprzętu macierzystej eskadry. Podobnie jak u Turbiaka, w jego narracji można też znaleźć informacje o taktyce. Poza tym Lewandowski bardziej szczegółowo wypowiedział się o najważniejszych lotach 15 EM (w tym własnych).

Na podstawie powyższych wspomnień oraz niektórych materiałów archiwalnych jeszcze przed wybuchem II wojny światowej powstał wartościowy

${ }^{2}$ Bitwa lwowska i zamojska 25 VII-18 X 1920, cz. I: 25 VII-5 VIII, oprac. zesp. pod kier. M. Tarczyńskiego, Warszawa 2002; cz. II: 6-20 VIII, oprac. eidem, Warszawa 2004.

${ }^{3}$ T. Turbiak, Walki III Dywizjonu Lotniczego z konna armja Budiennego pod Lwowem. Wspomnienia i uwagi, „Bellona” 1922, t. V, z. 2.

${ }^{4}$ E. Lewandowski, Lotnictwo $w$ walce $z$ armja konna Budiennego, „Przegląd Lotniczy” 1932, nr 1/2; idem, Zarys historji 15-ej eskadry myśliwskiej (obecnie 132-ej), „Przegląd Lotniczy" 1929, nr 5. Lewandowski otrzymał awans na podpułkownika w $1930 \mathrm{r}$. 
artykuł poświęcony udziałowi lotnictwa w obronie Lwowa w 1920 r. ${ }^{5}$ Napisana przez Władysława Madejskiego publikacja łączyła cechy pracy historycznej z teoretycznymi rozważaniami, których celem było wyciągnięcie wniosków przydatnych dla Wojska Polskiego.

Po opublikowaniu artykułu Madejskiego nastąpiła ponad pięćdziesięcioletnia przerwa w badaniach nad tym zagadnieniem. W latach 1939-1945 wynikała ona z okupacji ziem polskich, a w ciągu kolejnych 45 lat - z odgórnej cenzury i panującej wśród historyków polskiego lotnictwa autocenzury. Dopiero w latach dziewięćdziesiątych XX w. powrócono do badania najdawniejszych dziejów polskiego lotnictwa wojskowego. Pierwsze prace miały charakter ogólnikowy bądź skupiały się na kwestiach technicznych. Do tej pierwszej grupy można zaliczyć kompleksowe opracowania na temat polskiego lotnictwa wojskowego w okresie walk o granice II Rzeczypospolitej. W 1991 r. pierwszą powojenną publikację tego rodzaju przedstawił Krzysztof Tarkowski ${ }^{6} .18$ lat później o tych samych wydarzeniach wypowiedział się Hubert Mordawski ${ }^{7}$. Obaj autorzy starali się opisać całą historię polskiego lotnictwa w latach 1918-1920. Siłą rzeczy narracja tycząca się sierpnia $1920 \mathrm{r}$. pod Lwowem była dość zdawkowa i z całą pewnością nie wyczerpała tematu. Podobnie rzecz się ma z prezentującą spojrzenie z nieco innej perspektywy na omawiane wydarzenia książką Andrzeja Olejki ${ }^{8}$.

Publikacje zajmujące się kwestiami technicznymi skupiały się na bardzo wąskim wycinku problemu wyartykułowanego w tytule niniejszego artykułu. Trudno przy ich pomocy stworzyć obraz działań polskiego lotnictwa pod Lwowem w sierpniu 1920 r. Bądź co bądź np. w artykule Tomasza Kopańskiego o jednym z Fokkerów D.VII 15 EM można znaleźć opis zakończonego przymusowym lądowaniem lotu por. Józefa Hendricksa9

Więcej informacji odnośnie do tytułowego problemu dostarczył Aleksander Smoliński w opublikowanym na łamach „Przeglądu Historyczno-Wojskowego” artykule o zmaganiach polskiego lotnictwa z 1 Armią Konną komandarma Budionnego $^{10}$. Choć autor znany jest głównie ze swych prac tyczących się bolszewickiej kawalerii, to jego rozważania o polskim lotnictwie także można ocenić jako bardzo wartościowe. Na zaledwie kilkunastu stronach przedsta-

\footnotetext{
${ }^{5}$ W. Madejski, Lotnictwo w bitwie pod Lwowem w sierpniu 1920 roku, „Przegląd Lotniczy” 1937, nr 4.

${ }^{6}$ K. A. Tarkowski, Lotnictwo polskie $w$ wojnie $z$ Rosja Sowiecka 1919-1920, Warszawa 1991.

${ }^{7}$ H. Mordawski, Polskie lotnictwo wojskowe 1918-1920. Narodziny i walka, Wrocław 2009.

${ }^{8}$ A. Olejko, Działania lotnicze w pasie karpackim w latach 1914-1947, Rzeszów 2005.

9 T. J. Kopański, Fokker DVII BI-BA-BO, „Lotnictwo z Szachownicą” 2002, nr 1.

${ }^{10}$ A. Smoliński, Udział lotnictwa Wojska Polskiego w walce $z$ I Armia Konna podczas kampanii 1920 r., „Przegląd Historyczno-Wojskowy” 2007, nr 1 (216).
} 
wił on jednak kilka miesięcy zmagań Wojsk Lotniczych z 1 Armią Konną, co wpłynęło negatywnie na stopień szczegółowości narracji. Nie sposób nie dostrzec przy tym swego rodzaju faworyzowania $7 \mathrm{EM} \mathrm{im}$. Tadeusza Kościuszki na tle pozostałych polskich eskadr.

Dość szczegółowych danych o udziale polskiego lotnictwa w powstrzymaniu 1 Armii Konnej na przedpolach Lwowa przyniosły ponadto monografie dwóch zasłużonych eskadr. W 2011 r. Tomasz Kopański wydał pracę odnoszącą się do $7 \mathrm{EM}^{11}$, natomiast siedem lat później światło dzienne ujrzała, napisana przez zespół ks. Roberta Kulczyńskiego, książka poświęcona 15 EM ${ }^{12}$.

Warto jeszcze dodać, że o sierpniowych bojach tej ostatniej jednostki lotniczej wypowiedział się Łukasz Łydżba. W 2009 r. jego artykuł ukazał się na łamach „Lotnictwa z Szachownicą" ${ }^{3}$.

\section{Teren}

Ważne miejsce we wspominanych publikacjach zajmowało omówienie udziału wymienionych jednostek lotniczych w pierwszym etapie bitwy na przedpolach Lwowa. Obszar tego etapu bitwy zasadniczo zawierał się w wielokącie, którego wierzchołkami były Kamionka Strumiłowa, Busk, Gliniany, Winniki i Żółkiew. Atakujące znad Bugu siły Armii Czerwonej nie miały - poza wspomnianą rzeką - poważniejszej przeszkody wodnej przed sobą. Znajdujące się na terenie przyszłej bitwy rzeczki i kanały przebiegały równoleżnikowo.

Teren był w dużej mierze zalesiony, w szczególności na odcinku północnym (między Kamionką Strumiłową a Żółkwią), a także na południu (w okolicach Zadwórza i Połonic). Dla 1 Armii Konnej oznaczało to utrudnienie w wykorzystywaniu swego głównego sposobu walki - manewru, ale z drugiej strony ułatwiało ukrycie się przed lotnikami. Poza tym nieliczne dukty leśne kanalizowały marsz jednostek Armii Czerwonej. Ułatwiało to realizowanie stawianych polskiemu lotnictwu zadań szturmowych i bombowych. Z drugiej strony zalesiony teren stanowił poważne utrudnienie lotniczej pracy rozpoznawczej. Dla wykrycia kawalerii w lesie niezbędne było wykonywanie lotu na jak najmniejszej wysokości. Zwiększało to szanse nieprzyjacielskiej obrony przeciwlotniczej. Doświadczenia z lipca 1920 r. wskazywały, że 1 Armia Konna pierwszorzędnie potrafiła organizować zasadzki na nisko lecące polskie samoloty ${ }^{14}$. W centrum przyszłego pola bitwy także znajdowały się

\footnotetext{
${ }^{11}$ T. J. Kopański, 7 Eskadra Myśliwska im. Tadeusza Kościuszki 1918-1921, Warszawa 2011.

${ }^{12}$ IV Eskadra Wielkopolska (15. Eskadra Myśliwska). 25 V 1919-29 VIII 1921, red. ks. R. Kulczyński SDB, Warszawa 2018.

${ }^{13}$ Ł. Łydżba, Fokkery w obronie Lwowa, „Lotnictwo z Szachownicą” 2009, nr 1.

${ }^{14}$ Szerzej na temat taktyki zwalczania polskich samolotów przez Konarmię oraz jej rezultatach zob. M. Niestrawski, Polskie Wojska Lotnicze w okresie walk o granice państwa
} 
lasy, ale ich powierzchnia była zdecydowanie mniejsza. Był to teren zasadniczo pagórkowaty.

Najważniejsze drogi biegły z Kulikowa do Lwowa (północ-południe), z Kamionki Strumiłowej przez Żółtańce do Lwowa (północny wschód-południowy zachód), a także z Podhajczyków przez Kurowice do Lwowa (wschód-zachód). Na tym terenie znajdowały się też dwie ważne linie kolejowe: z Kamionki Strumiłowej do Lwowa oraz z Krasnego do Lwowa (wschód-zachód). Do Krasnego prowadziły tory kolejowe z Brodów (ze wschodu) oraz z Tarnopola (z południowego wschodu).

\section{Warunki atmosferyczne}

W przypadku działań lotniczych czynnikiem o niebagatelnym znaczeniu są warunki pogodowe. $W$ epoce samolotów $z$ drewna i płótna odgrywały one jeszcze większą - niż kilka dekad później czy współcześnie - rolę. W polskim lotnictwie doby walk o granice II Rzeczypospolitej bez trudu można znaleźć liczne przykłady ograniczenia działań lotniczych z powodu pogody bądź też spowodowanych warunkami atmosferycznymi katastrof lotniczych ${ }^{15}$.

W dniach 9-19 sierpnia 1920 r. pogoda zasadniczo nie uniemożliwiała prowadzenia akcji lotniczych w Galicji Wschodniej. Trzeba jednak zaznaczyć, że np. 18 sierpnia mglisty poranek znacząco opóźnił starty z lotniska Lewandówka. Kolejnymi dniami niesprzyjającej pogody były 21 i 22 sierpnia, gdy niska podstawa chmur utrudniła działania polskiego lotnictwa, ale to już wykracza poza ramy chronologiczne tego artykułu.

\section{Siły Armii Czerwonej}

Maszerująca na Lwów 1 Armia Konna Budionnego była najwartościowszym bolszewickim zgrupowaniem kawalerii użytym na froncie przeciwpolskim w 1920 r. Na początku sierpnia 1920 r. w skład Armii wchodziło pięć gotowych do walki dywizji kawalerii (DK): 4, 6, 8, 11 i 14. Do tego Budionnemu podlegała też dopiero organizowana 19 DK, a także 45, 47 oraz 24 Dywizja Strzelecka (DS). W dniu 1 sierpnia stan bojowy całej armii wynosił 26,5 tys. ludzi, a stan żywieniowy - ponad 54 tys. żołnierzy. Armia dysponowała niemal 46 tys. koni ${ }^{16}$.

Należy jednak zaznaczyć, że wkrótce siły Budionnego zostały uszczuplone. 3 sierpnia 8 DK Czerwonego Kozactwa oraz 45 DS utworzyły Odcinek Bojowy Kierunku Złoczowskiego, którego dowódcą został komdyw Jona Jakir.

\footnotetext{
polskiego, t. II: Walka i demobilizacja, Oświęcim 2017, s. 160-162.

${ }^{15}$ Zob. np. ibidem, s. 25, 45, 50, 52, 99-101, 107, 165-166, 279.

${ }^{16}$ A. Smoliński, 1 Armia Konna podczas walk na polskim teatrze działań wojennych w 1920 roku, Torun 2008, s. 293, 298.
} 
7 sierpnia grupę tę zasiliła ponadto 47 DS. 16 sierpnia powyższe siły oddano dowództwu $14 \mathrm{Armii}^{17}$. Bez wątpienia był to poważny cios dla planującego zajęcie Lwowa Budionnego.

Stan bojowy pozostawionych Budionnemu wielkich jednostek kawalerii przedstawiał się następująco (na dzień 1 sierpnia 1920 r.): 4 DK - niemal 1,2 tys. szabel, ponad 100 karabinów maszynowych i 11 dział; 6 DK - ponad 5,2 tys. szabel, niemal 90 karabinów maszynowych i 12 dział; $11 \mathrm{DK}$ - prawie 200 bagnetów, niemal 1,7 tys. szabel, ponad 30 karabinów maszynowych i 9 dział; natomiast $14 \mathrm{DK}$ - prawie 400 bagnetów, ponad 1,9 tys. szabel, prawie 80 karabinów maszynowych i $12 \mathrm{dzia}^{18}{ }^{18}$. W sumie stan bojowy tych czterech dywizji wynosił: 10,6 tys. ludzi, ok. 300 karabinów maszynowych i 44 działa. Dla porównania, w dniu 25 sierpnia było to: 14,5 tys. ludzi, ok. 300 karabinów maszynowych i 51 dział ${ }^{19}$.

Wsparcie jednostkom kawalerii zapewniały pociągi pancerne, oddziały samochodów pancernych oraz lotnictwo. Wkraczając na front polski $1 \mathrm{Ar}-$ mia Konna dysponowała trzema oddziałami lotniczymi: 24, 36 i 41. Jeszcze $\mathrm{w}$ połowie lipca posiadały one w sumie 19 samolotów. Reprezentowane były: S.E.5 (dwa), Nieuport 10C1 (jeden), Nieuport 17C1 (jeden), Nieuport 24C1bis (jeden), SPAD (jeden), RE.8 (jeden), Sopwith (cztery, co najmniej jeden Sopwith F.1 Camel), DH.9 (pięć), DH.11 (dwa) oraz Farman F.30 (jeden). $\mathrm{Z}$ całego tego wykazu tylko pięć samolotów było gotowych do lotu (jeden Nieuport 24C1bis w 24 Oddziale Lotniczym, jeden DH.11 w 36 Oddziale Lotniczym oraz dwa DH.9 i Sopwith Camel w 41 Oddziale Lotniczym). Pod względem materiałowym lotnictwo 1 Armii Konnej prezentowało się dość okazale. Jego problemem był niedobór wyszkolonego personelu latającego. Siłami powietrznymi Budionnego dowodzili byli oficerowie armii carskiej, którzy z samolotów zdatnych do lotu stworzyli Grupę Bojową. Podobnie jak kadra dowódcza, także większość pozostałego personelu latającego wywodziła się z dawnej Armii Rosyjskiej ${ }^{20}$. Lotnictwo 1 Armii Konnej nie odegrało w zasadzie żadnej poważniejszej roli w nadchodzącej bitwie ${ }^{21}$.

${ }^{17}$ Ibidem, s. 303 .

${ }^{18}$ Ibidem, s. 299, tab. 19.

${ }^{19}$ Ibidem, s. 303. Wzrost stanu bojowego po przegranej bitwie mógłby zaskakiwać. Został osiągnięty w znacznej mierze dzięki przysyłanym uzupełnieniom, wciągnięciu do jednostek bojowych żołnierzy z formacji tyłowych, a także wcielaniu rekrutów z zajętych terenów (ibidem, s. 304-305). Trzeba też zwrócić uwagę, że stan w dniu 1 sierpnia był prawdopodobnie niższy aniżeli tydzień później. Kończyła się bowiem dopiero krwawa bitwa pod Brodami, a kolejne kilka dni stanowiły dla 1 Armii Konnej czas wytchnienia.

${ }^{20}$ Ordre de Bataille armii bolszewickich przed odcinkiem własnego frontu z 27 lipca 1920 roku oraz Ordre de Bataille bolszewickiego Frontu Południowo-Zachodniego z 4 sierpnia 1920 roku [w:] Bitwa lwowska..., cz. I, s. 254-258, 842-851.

${ }^{21}$ Pojawiające się w Internecie wzmianki o obecności bolszewickich samolotów w czasie bitwy pod Zadwórzem nie znajdują potwierdzenia w polskiej i rosyjskiej literaturze fachowej. 


\section{Plan Armii Czerwonej}

Pierwotny plan dowództwa Armii Czerwonej na 1920 r. zakładał przeprowadzenie decydującej ofensywy przeciwko Polsce za pomocą Frontu Zachodniego komandarma Michaiła Tuchaczewskiego. Pod jego dowództwem miały znaleźć się wszystkie siły na froncie polskim. Tuchaczewski rozpoczął swą ofensywę letnią 4 lipca. Wkrótce po tym dniu ujawniło się, że dowodzący Frontem Południowo-Zachodnim komandarm Aleksander Jegorow nie godził się na ustaloną hierarchię. Ze względów ambicjonalnych, wspierany przez członka rady rewolucyjnej swego Frontu Józefa Stalina, dążył do uprzedzenia Tuchaczewskiego $w$ dotarciu na rdzenne ziemie polskie ${ }^{22}$.

Ostatecznie jeszcze w lipcu 1920 r. dowodzący Armią Czerwoną gławkom Siergiej Kamieniew zmodyfikował plan podboju Polski według życzeń Józefa Stalina. Front Południowo-Zachodni i Front Zachodni miały działać na rozbieżnych kierunkach. Od sił Jegorowa oczekiwano dalszego marszu na zachód. 1 Armia Konna miała napierać po linii Beresteczko-Rawa Ruska-Jarosław. 24 lipca Jegorow nakazał komandarmowi Budionnemu zajęcie Lwowa $^{23}$. Po zdobyciu stolicy Galicji Front Południowo-Zachodni miał przechwycić przeprawy przez San i przełęcze karpackie. Pozwoliłoby to zanieść „kaganek bolszewizmu” na Węgry i dalej na Bałkany ${ }^{24}$.

Wprawdzie na początku sierpnia władze partyjne zaczęły naciskać na Jegorowa, by przekazał Frontowi Zachodniemu 12 Armię, 1 Armię Konną, a nawet 14 Armię, ale postanowienia te były sabotowane przez dowództwo Frontu Południowo-Zachodniego. Poza tym, przynajmniej początkowo, przeświadczeni o rychłym upadku Warszawy Kamieniew i Tuchaczewski nie żądali z całą mocą oddania tych sił ${ }^{25}$. Gdy wreszcie, na początku drugiej dekady sierpnia, zmuszono Jegorowa do odstąpienia 12 Armii i 1 Armii Konnej Tuchaczewskiemu, to w toku była już ofensywa Budionnego na Lwów. Dowódca Konarmii był pewny zajęcia Lwowa z marszu i nie opracował bardziej szczegółowego planu walk o miasto.

\section{Sily strony polskiej}

Od chwili rozpoczęcia polskiego odwrotu z Kijowa 10 czerwca 1920 r. za obronę Galicji Wschodniej odpowiadały 3 i 6 Armia oraz ukraińska Armia Czynna. W końcu miesiąca reaktywowano wprawdzie 2 Armię, ale

\footnotetext{
${ }^{22}$ L. Wyszczelski, Lwów 1920, Warszawa 2014, s. 33-35.

${ }^{23}$ Ibidem, s. 40-41.

${ }^{24}$ J. S. Tym, Obrona Lwowa w sierpniu 1920 roku, https://www.ipsb.nina.gov.pl/a/artykul/ obrona-lwowa-w-sierpniu-1920-roku (dostęp 5 IV 2020).
}

${ }^{25}$ L. Wyszczelski, Lwów 1920..., s. 59-60. 
na początku sierpnia została ona rozwiązana. $\mathrm{W}$ tym samym czasie $3 \mathrm{Ar}$ mia otrzymała do wykonania ważne zadanie $w$ ramach przygotowywanej operacji warszawskiej. W związku z planowaniem kontrofensywy przeciw Tuchaczewskiemu z południowego odcinka frontu odwołano na północ szereg jednostek, między innymi: 18 Dywizję Piechoty (DP), 65 Pułk Piechoty (pp), 2 Dywizję Jazdy (DJ) i IV Kombinowaną Brygadę Jazdy (BJ) ${ }^{26}$.

Tym samym za obronę Galicji Wschodniej, a także za wiązanie sił Armii Czerwonej na południowym odcinku frontu odpowiadały wyłącznie 6 Armia i ukraińska Armia Czynna. W przypadku bezpośredniej obrony Lwowa można było jednak liczyć tylko na pierwszą z nich. Spośród jej jednostek (6, 12 i 13 DP, Grupa gen. por. Pawła Szymańskiego, 1 DJ oraz I BJ) w połowie sierpnia pomiędzy Kamionką Strumiłową a Lwowem znajdowała się tylko $6 \mathrm{DP}$ (w rzeczywistej sile brygady piechoty wzmocnionej przez oddziały ochotnicze). Grupa Szymańskiego (16 sierpnia przemianowana na 5 DP) znajdowała się znacząco na północ od Kulikowa. 13 DP stała na południe od Biłki Szlacheckiej. Jeszcze dalej znajdowała się 12 DP (pod Przemyślanami) oraz jazda (niemal pod Krystynopolem) ${ }^{27}$.

Przeprawa Budionnego przez Bug wymusiła reorganizację polskich sił. Dla wyrzucenia Budionnego za rzekę powołano nową, wchodzącą w skład Frontu Południowego, 6 Armię pod dowództwem gen. por. Władysława Jędrzejewskiego. Jej trzy wielkie jednostki (5, 6 i 13 DP) miały działać na kierunkach Żółkiew-Kamionka Strumiłowa, Lwów-Żółtańce-Toporów oraz Lwów-Krasne. 1 DJ nakazano utrzymanie łączności na północy z 3 Armią. Południową flankę 6 Armii miała asekurować 12 DP, której prawym sąsiadem była sojusznicza Armia Czynna gen. Mychajło Omelianowicza-Pawlenki. Wszystkie te formacje skrzydłowe podlegały bezpośrednio dowództwu Frontu Południowego gen. por. Wacława Iwaszkiewicza ${ }^{28}$.

\section{Polskie siły lotnicze}

Ofensywa Budionnego na Lwów zbiegła się w czasie z reorganizacją polskiego lotnictwa na froncie polsko-bolszewickim. Większość sił lotniczych Naczelne Dowództwo Wojska Polskiego (NDWP) zdecydowało się umieścić na północnym i środkowym odcinku frontu, by maksymalnie wesprzeć piechotę w czasie nadchodzącej operacji warszawskiej. Dla obrońców Galicji przewidziano skromną, acz proporcjonalną w stosunku do możliwości dotację lotniczą. Pierwotny rozkaz mówił o oddaniu Frontowi Południowemu:

\footnotetext{
${ }^{26}$ Rozkaz organizacyjny nr 9 dowództwa Frontu Południowo-Wschodniego [w:] Bitwa lwowska..., cz. I, s. 840-841.

${ }^{27}$ Rozkaz operacyjny nr 4 z 16 sierpnia 1920 r. [w:] ibidem, cz. II, s. 500-501.

${ }^{28}$ Rozkaz organizacyjny nr 9 dowództwa Frontu Poludniowo-Wschodniego...
} 
5 i 6 EW oraz 7 EM im. T. Kościuszki. Wszystkie trzy, obok III Ruchomego Parku Lotniczego, wchodziły w skład III DL ${ }^{29}$.

Przez przeszło rok na czele III DL (do kwietnia 1920 r. III Grupy Lotniczej) stał kpt. pil. Stefan Bastyr, który jednak 6 sierpnia 1920 r. poniósł śmierć w czasie oblotu samolotu myśliwskiego Fokker D.VII. Począwszy od 9 sierpnia, dowódcą dywizjonu, a zarazem zwierzchnikiem lotnictwa Frontu Południowego, był amerykański ochotnik mjr. pil. Cedric Faunt le Roy ${ }^{30}$. Stanowisko oficera taktycznego pełnił por. obs. Kazimierz Kubala, a adiutanta - por. obs. Adam Paleolog. Czwartym lotnikiem w sztabie dywizjonu był pchor. obs. Zygfryd Piątkowski ${ }^{31}$.

5 EW dowodził wówczas por. pil. Władysław Kalkus, 6 EW - por. pil. Adolf Wiesiołowski, natomiast 7 EM - kolejny z amerykańskich ochotników, por. pil. George Crawford. W każdej z eskadr wywiadowczych latało w sierpniu 5-6 pilotów i 6-7 obserwatorów, a w 7 EM - 6 pilotów. Doświadczenie i poziom umiejętności lotników stały na bardzo różnym poziomie. Miało to swoje późniejsze odzwierciedlenie w zróżnicowanej liczbie lotów bojowych. Zasadniczo więcej zadań w powietrzu wykonywali dobrzy piloci i solidni obserwatorzy (pod warunkiem, że byli zdrowi) ${ }^{32}$.

Podstawę wyposażenia 5 i 6 EW stanowiły jednosilnikowe angielskie lekkie bombowce Airco DH.9. Do Polski Brytyjczycy przesyłali je od wiosny 1920 r. i stanowiły one część daru rządu brytyjskiego. Ich rzeczywista przydatność bojowa była zróżnicowana. Część skasowano, choć nie wykonały żadnego lotu bojowego $^{33}$. W tym miejscu trzeba zaznaczyć, że w Polsce wykorzystywano je w taki sam sposób jak wszelkie inne samoloty dwumiejscowe - do rozpoznania i zrzucania niewielkich bomb. 7 EM wykorzystywała głównie włoskie jednomiejscowe samoloty myśliwskie Ansaldo A.1 Balilla. Ponadto w III DL znajdowały się mniej lub bardziej liczne wywiadowcze DFW C.V,

\footnotetext{
${ }^{29}$ Rozkaz Szefostwa Lotnictwa NDWP w sprawie przegrupowania Wojsk Lotniczych na froncie z 11 sierpnia 1920 r. [w:] Bitwa lwowska..., cz. II, s. 303-305. Zob. też T. Cybulski, Lotnictwo w operacji warszawskiej. W dziesięciolecie zwycięstwa nad Wisła, „Przegląd Lotniczy” 1930, nr 7/8, s. 502; W. Madejski, Lotnictwo w bitwie..., s. 456, 460; H. Mordawski, Polskie lotnictwo..., s. 288-290, 311.

${ }^{30}$ K. A. Tarkowski, Lotnictwo polskie..., s. 74, 78, 100. Zob. też T. J. Kopański, 7 Eskadra Myśliwska..., s. 99.

${ }^{31}$ Centralne Archiwum Wojskowe Wojskowego Biura Historycznego (dalej: CAW-WBH), Szefostwo Lotnictwa Naczelnego Dowództwa Wojska Polskiego (dalej: Szef. Lot. NDWP), sygn. I.301.12.26, Sumaryczne zestawienie lotów III Dyw. Lotniczego za miesiąc sierpień 1920 roku z dnia 1.IX.20., b.m., b.p.

${ }^{32}$ Ibidem.

${ }_{33}$ T. J. Kopański, Samoloty brytyjskie w lotnictwie polskim 1918-1930, Warszawa 2001, s. 8-9. Zob. też A. Morgała, Samoloty wojskowe w Polsce 1918-1924, Warszawa 1997, s. 61-62, $71,160$.
} 


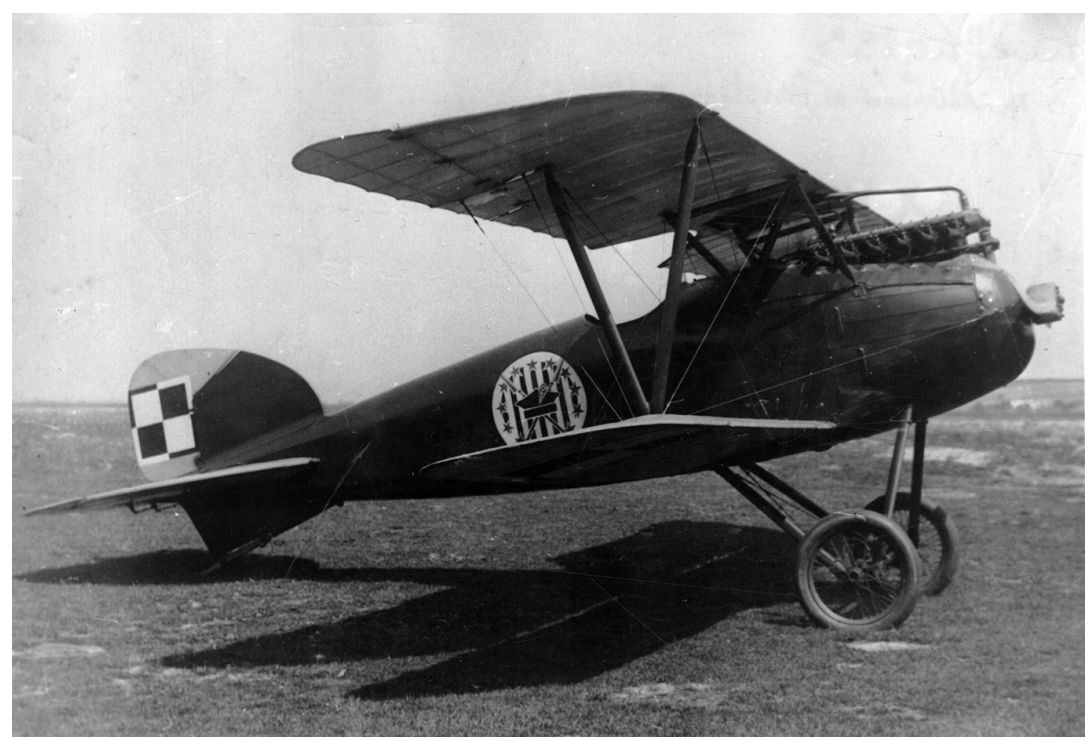

Fot. 1. Samolot myśliwski Oeffag D.III ze składu 7 Eskadry Myśliwskiej im. T. Kościuszki. Na fotografii egzemplarz o numerze austro-węgierskim 253.234. Od sierpnia 1919 do lipca 1921 r. latał w 7 Eskadrze Bojowej (Myśliwskiej). W listopadzie 1921 r. został kompletnie odbudowany w warsztatach krakowskiego 2 Pułku Lotniczego. Nadano mu wówczas numer K234, który można dostrzec na boku kadłuba Źródło: zdjęcie ze zbiorów Muzeum Lotnictwa Polskiego w Krakowie

LVG C.V, Hansa-Brandenburg C.I, a także myśliwskie Oeffagi D.III. Te ostatnie stanowiły podstawę wyposażenia $7 \mathrm{EM}$ we wcześniejszym okresie. Hansa-Brandenburgi C.I w pierwszej połowie $1920 \mathrm{r}$. wykorzystywano przede wszystkim w 6 EW. DFW C.V i LVG C.V były natomiast konstrukcjami bardzo rozpowszechnionymi w całych polskich Wojskach Lotniczych.

W omawianym okresie w dywizjonie znajdowało się najczęściej kilkanaście sprawnych maszyn. Przykładowo w dniu 12 sierpnia mjr Faunt le Roy mógł liczyć na zaledwie 10 zdolnych do lotu samolotów. O wartości bojowej tych „zdolnych do lotu” płatowców najlepiej świadczy cytat ze sprawozdania technicznego III DL za okres 10-25 sierpnia 1920 r.: „Zużycie aparatów i motorów czyni z każdego lotu eksperyment, względnie paraliżuje najszczersze wysiłki obsady i obsługi" ${ }^{34}$. Nie była to opinia odosobniona. W podobnym tonie wypowiedział się także Turbiak: „Personel latający, wypróbowany, pewny siebie, $\mathrm{z}$ dużem doświadczeniem bojowem - przeważnie weterani wojny światowej. Niestety i samoloty były też weteranami tej wojny światowej” ${ }^{35}$. Dalej Turbiak kontynuował: „Eskadry wywiadowcze uzbrojone były

\footnotetext{
${ }^{34}$ Cyt. za: W. Madejski, Lotnictwo w bitwie..., s. 460.

${ }^{35}$ T. Turbiak, Walki III Dywizjonu..., s. 124.
} 
w stare typy samolotów austrjackich, niemieckich, o małej nośności z motorami, które już dawno odsłużyły wszystkie terminy, przepisane warunkami technicznemi" 36 . Polskim eskadrom doskwierał ponadto niedobór bomb, głównie tych najmniejszych, a szczególnie bomb odłamkowych. Posiadane nadawały się raczej do niszczenia baraków, budynków, składów, pociągów, czy stacji kolejowych, a nie do zwalczania siły żywej. Dysponowały dużą siłą wybuchu, ale niewielkim rozrzutem odłamków. Pewne niedobory były związane również z amunicją, materiałami pędnymi i częściami zamiennymi ${ }^{37}$. Samoloty oznaczone biało-czerwonymi szachownicami nie miały wówczas zamontowanych wyrzutników, celowników bombowych, radiostacji, ani podchwytywaczy, a karabiny maszynowe pilotów były na wyposażeniu tylko niektórych maszyn ${ }^{38}$.

Poważne wzmocnienie III DL nastąpiło w dniu 13 sierpnia. Tamtego dnia przeznaczona pierwotnie do wsparcia Grupy Uderzeniowej marsz. Józefa Piłsudskiego 15 EM wykazała wielką wartość w zwalczaniu kawalerii. Sztab Frontu Południowego poprosił więc około godz. 15:00 NDWP o pozostawienie eskadry na południowym odcinku frontu: „Wobec faktu, że front 6 armii rozszerzył się oraz armia Budiennego [Budionnego - M. N.] naciska na Lwów, a do zwalczania jej nadają się przede wszystkim aparaty bojowe z k.m. [karabinami maszynowymi pilotów - M. N.], gdy tymczasem 7 esk. boj. [eskadra - M. N.] posiada tylko 2 aparaty z k.m., a działalność 15 esk. boj. może być bardziej celowa i z większym skutkiem użyta przeciw kawalerii niż przeciw piechocie, upraszam o pozostawienie do dyspozycji mjra Faunt le Roy szefa lotn. Frontu południowego 15 esk. boj. aż do czasu zlikwidowania armii Budiennego lub wyposażenia 7 esk. boj. w aparaty z k.m. Ze względu na toczącą się akcję proszę o odwrotną odpowiedź, czy można użyć 15-tej esk. lotn. do walki"39.

Odpowiedź była przychylna i dowodzona przez por. pil. Jerzego Dziembowskiego eskadra zasiliła III DL. Dziembowskiemu podlegało w tym czasie czterech pilotów. Podstawę wyposażenia stanowiło sześć niemieckich Fokkerów D.VII. Pojawiające się w wykazach pojedyncze francuskie myśliwce SPAD S.VIIC1 były niesprawne bądź nie zostały zmontowane ${ }^{40}$.

\footnotetext{
${ }^{36}$ Ibidem.

${ }^{37}$ Ibidem.

${ }^{38}$ W. Madejski, Lotnictwo w bitwie..., s. 460.

${ }^{39}$ Cyt. za: ibidem, s. 466-467.

${ }^{40}$ CAW-WBH, Dowództwo Lotnictwa Ministerstwa Spraw Wojskowych (dalej: D. Lot. MSWojsk.), sygn. I.300.38.38, Wykaz lotów bojowych polskiego lotnictwa, b.m., b.d., b.p. Zob. też IV Eskadra Wielkopolska..., s. 100-101; E. Lewandowski, Lotnictwo w walce..., s. 31; Ł. Łydżba, Fokkery w obronie..., s. 28; W. Madejski, Lotnictwo w bitwie..., s. 466. Wśród posiadanego przez III DL sprzętu jeden z uczestników walk, Edward Lewandowski,
} 


\section{Plan strony polskiej}

Podobnie jak Armia Czerwona, także Wojsko Polskie nie stworzyło szczegółowej koncepcji stoczenia bitwy obronnej na przedpolach Lwowa. NDWP oczekiwało tylko przesłaniania Lwowa i Borysławsko-Drohobyckiego Zagłębia Naftowego. Gen. Iwaszkiewicz zdecydował się zrealizować to zadanie, broniąc linearnie Galicji Wschodniej od granicy z Rumunią aż do linii Bugu. Wobec silnego, a przede wszystkim ruchliwego przeciwnika była to koncepcja bardzo ryzykowna. Zresztą do połowy sierpnia strona polska nie przewidywała nawet konieczności stoczenia bitwy obronnej o Lwów ${ }^{41}$.

Po sforsowaniu Bugu przez Budionnego i dostrzeżeniu przez polskich dowódców jego oczywistego celu w postaci zajęcia Lwowa, pojawiły się nieco bardziej szczegółowe wytyczne odnośnie do działań jednostek Wojska Polskiego w Galicji Wschodniej. Generała porucznika Jędrzejewskiego zobowiązano do prowadzenia obrony ruchowej. Dywizje 6 Armii miały utrzymać swe pasy działania i rejony koncentracji, z których powinny działać energicznie, starając się rozbijać każde ugrupowanie bolszewickie ${ }^{42}$.

Wielkie jednostki 6 Armii były jednak rozrzucone na dużym obszarze i nie miały możliwości szybkiego włączenia się do bitwy. Jedynym odwodem 6 Armii był III DL. Otrzymał on rozkaz maksymalnego spowolnienia postępów Budionnego ${ }^{43}$.

\section{Taktyka polskiego lotnictwa}

Zastosowana w czasie walk o Lwów taktyka polskiego lotnictwa pozornie była zaprzeczeniem zasad sztuki wojennej. Samoloty uderzały nie jednocześnie $\mathrm{w}$ jednym miejscu, ale prowadziły naloty nękające pojedynczymi maszynami nad całym obszarem, przez cały dzień. Biorąc pod uwagę wyznaczony polskim lotnikom cel - spowolnienie, a nie zniszczenie 1 Armii Konnej wybór tej taktyki wydaje się uzasadniony, choć była ona ryzykowna i mogła się wiązać ze stosunkowo wysokimi stratami własnymi przy niewielkiej szkodzie dla przeciwnika.

wymienił także niemieckiego Fokkera E.V. (zob. E. Lewandowski, Lotnictwo w walce..., s. 31). Co interesujące, taki samolot w otoczeniu Fokkerów D.VII jest widoczny na niektórych zdjęciach archiwalnych z 1920 r. Dzięki benedyktyńskiej pracy zespołu ks. Roberta Kulczyńskiego można jednak stwierdzić, że Fokker z silnikiem rotacyjnym trafił do 15 EM dopiero 11 września i nie został użyty bojowo, zob. IV Eskadra Wielkopolska..., s. 124, 132.

${ }^{41}$ L. Wyszczelski, Lwów 1920..., s. 113-116, 122.

${ }^{42}$ Rozkaz operacyjny $n r 4$ z 16 sierpnia 1920 r. [w:] Bitwa lwowska..., cz. II, s. 500-501.

${ }^{43}$ A. Olejko, Działania lotnicze..., s. 127-128. Zob. też K. A. Tarkowski, Lotnictwo polskie..., s. 101. 
By pokazać, jak w szczegółach przedstawiała się taktyka użycia III DL, najlepiej oddać głos uczestnikowi tych zmagań - ppor. obs. Turbiakowi. Zasłużony oficer (wówczas już porucznik) pisał w 1922 r.:

„Aby sztucznie zwiększyć ilość [liczbę - M. N.] samolotów, dowódcy poszczególnych eskadr wysyłali samolot za samolotem bez przerwy - nie zbierając ich w plutony czy patrole, aby nie tracić czasu na oczekiwanie.

Samolot zabierał bomby, naboje do karabinów maszynowych, startował - leciał na front - rzucał bomby, atakował karabinem maszynowym - wracał. Lotnicy dawali ustne sprawozdanie w dywizjonie na lotnisku z lotów, walk i posunięć nieprzyjaciela, mechanicy napełniali zbiorniki benzyną i oliwą, ładowali bomby, amunicją [amunicję - M. N.] do karabinów maszynowych i samolot znów startował.

Chociaż samoloty latały pojedynczo, nad terenem, którędy maszerowały masy jazdy Budiennego [Budionnego - M. N.], zawsze było kilka samolotów w powietrzu, przez co utrzymywało się ciągłość ataków.

Poprzednie doświadczenie bojowe III Dyonu Lotn. wykazało, że atakowanie wojsk na ziemi musi być poprzedzone energicznym bombardowaniem. Bombardowanie denerwuje - demoralizuje nieprzyjaciela, a kilka udatnie [sic!] rzuconych bomb sieje panikę, zmniejsza ogień obronny wojsk na ziemi i czyni go mało szkodliwym dla lotnika.

Konieczność bombardowania była tak oczywista, iż samoloty jednosiedzeniowe, z budowy swej przeznaczone do walki tylko karabinami maszynowemi, zabierały bomby jak się dało, czasami na kolana pilota, aby tylko nie pozbawić się tak potężnego środka walki, jakim jest bomba.

Taktyka walki była taka: Samoloty, rozsiane w przestworzach nad całym terenem marszu, zaczynały walkę od bombardowania z wysokości 700-800 metrów poszczególnych kolumn i skupień nieprzyjaciela. Wysokość taka musiała być utrzymana $\mathrm{z}$ dwóch powodów: 1) bomby, które posiadano, z mniejszej wysokości nie zawsze wybuchały; 2) ogień karabinów maszynowych i zwykłych, ostrzeliwujący samoloty, na tej wysokości jest mało skuteczny. Bombardowanie wywierało swój skutek - samoloty zniżały się do nieznacznej wysokości, aby gwałtownie atakować karabinami maszynowemi. I wtedy zaczynało się piekło. Świst skrzydeł, szum motoru, gorączkowy ogień broni ręcznej i karabinów maszynowych wojsk na ziemi, zagłuszający wszystko, zlewały się w jeden straszny 
chaos. Oszalałe ze strachu konie, z pochylonymi nad ich karkami jeźdźcami, rwały w jakimś furiackim pędzie na oślep przed siebie na wszystkie strony. Spadają jeźdźcy - wywracają się konie. Trwa to tylko minuty, samolot wystrzelawszy całą amunicję, musi opuścić plac boju. Ponieważ jedne samoloty dopiero co przyleciały, więc zaczynają bombardowanie; inne, wyrzuciwszy bomby, zaczynają gwałtowny atak karabinami maszynowemi. Huk wybuchów bomb i turkot k. m. trwał od rana bez przerwy. Jazda Budiennego ani chwili nie miała spokoju.

Około południa już dał się zauważyć rezultat ataków. Rano tylko bezpośrednio atakowane kolumny rozpraszały się; czoło kolumny maszerowało spokojnie, gdy był atakowany tył. W południe każda maszerująca kolumna przy zbliżaniu się samolotu rozsypywała się na wszystkie strony galopem, starając się ukryć pod drzewami, albo we wsiach. Tabory, rażone bombami, przy zbliżaniu się samolotu pędziły w bok od drogi jak rozpełzające się robactwo. Wsie Kupcze, Kozłów, Przepniów [Rzepniów - M. N.], Żelechów, Milatyn, Lisko i Kędzierzawce, w których próbował chronić się nieprzyjaciel nie były dobrą ochroną, bomby raziły i tam, a kawalerzyści, porzucając konie, kryli się do chałup przed ogniem karabinów maszynowych"44.

Turbiak przedstawił taktykę, pisząc o akcjach z dnia 16 sierpnia, ale można domniemywać, że była ona stosowana również przez pozostałe dni wytężonego wysiłku III DL. W czasie lotów rozpoznawczych najważniejsza była informacja, więc nie ryzykowano tego rodzaju ataków z broni maszynowej. Stałym elementem lotów rozpoznawczych było jednak zrzucanie bomb na zauważonego nieprzyjaciela.

\section{Okres działań rozpoznawczych (9-12 sierpnia)}

Na przełomie lipca i sierpnia 1920 r. została stoczona bitwa pod Brodami. Jej celem było osłabienie 1 Armii Konnej, by ta nie zagroziła polskiej koncentracji do ogólnej kontrofensywy na północnym odcinku frontu. 2 sierpnia bitwa ta została zakończona. Budionnego nie pobito, ale musiał on się wycofać za Ikwę i uporządkować swoje siły. Przez kolejnych kilka dni polskie lotnictwo latało dość rzadko.

Na początku drugiego tygodnia sierpnia III DL w dalszym ciągu latał stosunkowo niewiele. Każdego dnia wykonywano kilka misji o charakterze

${ }^{44}$ T. Turbiak, Walki III Dywizjonu..., s. 126-127. Podobnie, choć może mniej obrazowo, o taktyce polskich nalotów pod Lwowem wypowiedział się Edward Lewandowski, zob. idem, Zarys historji..., s. 379. 
rozpoznawczym. 9 sierpnia eskadry Frontu Południowego zrealizowały 5 lotów. Na nieprzyjaciela zrzuciły $70 \mathrm{~kg}$ bomb i wystrzeliły 100 pocisków ${ }^{45}$.

Wśród wspomnianych pięciu zadań w powietrzu najważniejsze zostało przeprowadzone wieczorem. Załoga 6 EW (chor. pil. Józef Cagašek i ppor. obs. Józef Wojciechowski) wykonała lot na północny wschód od Lwowa, wzdłuż trasy Brody-Stanisławczyk-Łopatyn-Bołdury-Leszniów-Beresteczko-Stojanów-Witków-Radziechów-Chołojów-Dmytrów-Majdan Stary-Toporów. Po locie obserwator złożył raport o obecności wielkich ognisk w lasach i zwiększonym ruchu taborów 1 Armii Konnej. Konarmia zdawała się kierować na Toporów i Chołojów. Sytuację na ziemi prawidłowo zinterpretowano jako zapowiedź zbliżającej się kolejnej ofensywy ${ }^{46}$.

Dla potwierdzenia i uzupełnienia tego meldunku dowództwo dywizjonu wysłało następnego dnia kolejną załogę ze składu $6 \mathrm{EW.} \mathrm{Za} \mathrm{sterami} \mathrm{samo-}$ lotu usiadł dowódca eskadry por. pil. Adolf Wiesiołowski, a towarzyszył mu ppor. obs. Stefan Tarasiewicz ${ }^{47}$.

Poza lotem Wiesiołowskiego i Tarasiewicza III DL wykonał 10 sierpnia jeszcze siedem lotów bojowych. Potwierdzono meldunki z poprzedniego dnia, stwierdzając, że jednostki Budionnego wyruszyły z Krzemieńca, Wiśniowca i Dunajowa na północny zachód. Loty rozpoznawcze wykonano między innymi nad Toporowem, Chołojowem, Witkowem i Beresteczkiem. Zaplanowana współpraca z polską kawalerią nie została zrealizowana. W ciągu całego dnia na pozycje Armii Czerwonej zrzucono $250 \mathrm{~kg}$ bomb i wystrzelono 650 pocisków ${ }^{48}$.

Dnia 11 sierpnia lotnictwo Frontu Południowego wykonało trzynaście lotów. W czasie ich trwania obserwowało postępy wojsk Budionnego, a także ustalało kierunki odwrotu pobitych polskich jednostek. Zrzuciło $180 \mathrm{~kg}$ bomb i wystrzeliło 2250 pociskó $w^{49}$. Zadania w powietrzu wykonali tego dnia: por. pil. Hendricks z 15 EM, sierż. pil. Alojzy Styks i ppor. obs. Wojciechowski z 6 EW, ppor. Aleksander Seńkowski oraz por. pil. Crawford z 7 EM, a także dowódca dywizjonu mjr pil. Faunt le Roy ${ }^{50}$.

${ }^{45}$ CAW-WBH, Szef. Lot. NDWP, sygn. I.301.12.26, Działalność III Dywizjonu Lotniczego za miesiąc sierpień 1920 r. z 1 października 1920 r., b.m., b.p.

${ }^{46}$ Raport z rozpoznania lotniczego ppor. obs. Józefa Wojciechowskiego z 9 sierpnia $1920 \mathrm{r}$. [w:] Bitwa lwowska..., cz. II, s. 236-237. Zob. też H. Mordawski, Polskie lotnictwo..., s. 311.

${ }^{47}$ CAW-WBH, D. Lot. MSWojsk., sygn. I.300.38.38, Wykaz lotów bojowych polskiego lotnictwa, b.m, b.d., b.p.

${ }^{48}$ CAW-WBH, Szef. Lot. NDWP, sygn. I.301.12.26, Działalność III Dywizjonu Lotniczego za miesiąc sierpień 1920 r. z 1 października 1920 r., b.m., b.p.

${ }^{49}$ Ibidem.

${ }^{50}$ CAW-WBH, D. Lot. MSWojsk., sygn. I.300.38.38, Wykaz lotów bojowych polskiego lotnictwa, b.m, b.d., b.p. 
W tym czasie ofensywa 1 Armii Konnej nabierała rozmachu. Po odwrocie polskiej 3 Armii na linię Bugu Budionny zaatakował Beresteczko i Łopatyn. Natomiast po cofnięciu się polskiej jazdy na Krystynopol dowódca 1 Armii Konnej podszedł pod Chołojów. 12 sierpnia 6 Armia została zepchnięta na linię Bugu i Strypy.

Polskie sztaby otrzymywały informacje o ciągle tlących się bojach z 1 Armią Konną pod Brodami, a także o obecności oddziałów Budionnego w Poczajowie, Beresteczku, Sieńkowie, Ohladowie i Stojanowie ${ }^{51}$.

12 sierpnia zaangażowanie III DL nieco się zmniejszyło. Można domniemywać, że przyczyną tego były warunki atmosferyczne, bowiem Dywizjon dysponował liczbą 10 sprawnych maszyn. Mimo tego jego personel przeprowadził tylko dwa loty rozpoznawcze - jeden wykonał por. pil. Crawford ${ }^{52}$. Polskie lotnictwo nie odnalazło kawalerii Budionnego w dotychczasowym miejscu pobytu, więc dowódca dywizjonu mjr pil. Faunt le Roy postanowił wysłać kolejnego dnia następną załogę.

\section{Rosnące zaangażowanie lotnictwa (13-15 sierpnia)}

Rankiem 13 sierpnia wystartowała mieszana załoga w składzie plut. pil. Paweł Tissler z 6 EW oraz por. obs. Kubala z dowództwa dywizjonu. Trasa ich lotu biegła ze Lwowa, przez Toporów, Szczurowice, Redków, Beresteczko, Stojanów i Radziechów. Obserwator zauważył polskie tabory w Toporowie, Chołojowie, Sapieżance i Kamionce Strumiłowej. Ponadto do ostatniej z tych miejscowości wkraczały dwie kompanie piechoty. Kubala skontrolował przy okazji stan mostów na rzekach Radostawce oraz Styrze. Nieprzyjacielskie oddziały i tabory obserwator widział pod Monastyrkiem Ohładowskim, Szczurowicami, Mytnicą, Sobinem (pod Niemiłowem) i Śródopolcami ${ }^{53}$.

Meldunki z rozpoznania pozwoliły polskim sztabowcom ustalić, że trzy nieprzyjacielskie dywizje kawalerii maszerowały przez Beresteczko i Łopatyn na Majdan Stary, Ohladów, Radziechów i Kamionkę Strumiłową ${ }^{54}$. Nie dostrzeżono natomiast drugiej kolumny Budionnego, która kierowała

${ }^{51}$ Zestawienie wiadomości o nieprzyjacielu od dnia 10 sierpnia 1920 r. oraz Meldunek sytuacyjny wieczorny do dowództwa Grupy Operacyjnej Jazdy z 11 sierpnia 1920 r. [w:] Bitwa lwowska..., cz. II, s. 301-302, 334.

${ }^{52}$ CAW-WBH, D. Lot. MSWojsk., sygn. I.300.38.38, Wykaz lotów bojowych polskiego lotnictwa, b.m, b.d., b.p.

${ }^{53}$ Raport $z$ lotu rozpoznawczego por. obs. Kazimierza Kubali z III Dywizjonu Lotniczego z 13 sierpnia 1920 r. [w:] Bitwa lwowska..., cz. II, s. 419-420. Zob. też W. Madejski, Lotnictwo w bitwie..., s. 464-467; H. Mordawski, Polskie lotnictwo..., s. 312-313; A. Smoliński, Udziat lotnictwa..., s. 38 .

${ }^{54}$ CAW-WBH, Szef. Lot. NDWP, sygn. I.301.12.26, Działalność III Dywizjonu Lotniczego za miesiąc sierpień 1920 r. z 1 października 1920 r., b.m., b.p. 
się z Kozina na Brody, Toporów i Busk. Ostrze tego podwójnego uderzenia było wymierzone we Lwów ${ }^{55}$. Sztab Frontu Południowego pokładał nadal nadzieję na powstrzymanie Budionnego przez 1 DJ płk. Juliusza Rómmla oraz Grupę gen. por. Szymańskiego. W akcji mieli współuczestniczyć lotnicy, więc oddziały na ziemi zobowiązano do wykładania białych znaków rozpoznawczych ${ }^{56}$.

Identyfikacja oddziałów na ziemi była tak ważna, gdyż w zaistniałej sytuacji sztab Frontu Południowego nakazał dowódcy III DL bezpośrednie uderzenie lotnicze na 1 Armię Konną. Major Faunt le Roy wysłał kpt. pil. Edwarda Corsiego i ppor. pil. Seńkowskiego z 7 EM oraz wszystkich pięciu pilotów 15 EM (por. pil. Dziembowski, por. pil. Hendricks, ppor. pil. Antoni Bartkowiak, ppor. pil. Stanisław Rozmiarek i ppor. pil. Lewandowski). Corsi i czterej pierwsi z wymienionych pilotów 15 EM poza ostrzelaniem przeciwnika $z$ broni maszynowej zrzucili też bomby ${ }^{57}$. Po tym ataku sztab Frontu Południowego poprosił o pozostawienie 15 EM w Galicji Wschodniej.

III DL przeprowadził 13 sierpnia także kilka lotów rozpoznawczych. Jeden z nich wykonała załoga ze składu 5 EW: ppor. pil. Ludwik Nazimek i ppor. obs. Kazimierz Braun; a drugi - sierż. pil. Józef Rączka i ppor. obs. Wojciechowski z $6 \mathrm{EW}^{58}$.

W sumie dywizjon przeprowadził tego dnia 13 lotów. Na głowy bolszewików rzucono $116 \mathrm{~kg}$ bomb i wstrzelono 1,8 tys. pocisków. Szczególnie silne akcje bojowe III DL rozwinął nad Chołojowem, gdzie Budionnemu przeciwstawiła się polska kawaleria oraz pod Toporowem, bronionym przez oddziały ze składu $18 \mathrm{DP}^{59}$.

Jednostki 1 Armii Konnej naciskały ponadto na 6 DP i Grupę Szymańskiego. Mimo wszystko sztaby uważały sytuację za opanowaną i nie widziały jeszcze powodów do paniki ${ }^{60}$.

\footnotetext{
${ }^{55}$ E. Lewandowski, Lotnictwo w walce..., s. 29.

${ }^{56}$ Rozkaz operacyjny nr 1 z 13 sierpnia 1920 r. [w:] Bitwa lwowska..., cz. II, s. 418-419.

${ }^{57}$ CAW-WBH, D. Lot. MSWojsk., sygn. I.300.38.38, Wykaz lotów bojowych polskiego lotnictwa, b.m, b.d., b.p. Zob. też IV Eskadra Wielkopolska..., s. 100-101; E. Lewandowski, Lotnictwo $w$ walce..., s. 31; Ł. Łydżba, Fokkery w obronie..., s. 28; W. Madejski, Lotnictwo w bitwie..., s. 466. W narracji Aleksandra Smolińskiego znajduje się wzmianka o dwóch samolotach wysłanych przez 7 EM. Autor pisze jednak również o czterech, a nie pięciu maszynach z 15 EM, zob. A. Smoliński, Udziat lotnictwa..., s. 38.

${ }^{58}$ CAW-WBH, D. Lot. MSWojsk., sygn. I.300.38.38, Wykaz lotów bojowych polskiego lotnictwa, b.m, b.d., b.p.

${ }^{59}$ CAW-WBH, Szef. Lot. NDWP, sygn. I.301.12.26, Działalność III Dywizjonu Lotniczego za miesiąc sierpień 1920 r. z 1 października 1920 r., b.m., b.p.
}

${ }^{60}$ Komunikat operacyjny nr 4 z 13 sierpnia 1920 r. [w:] Bitwa lwowska..., cz. II, s. 420-421. 
14 sierpnia już cały III DL był zaangażowany w akcję przeciwko siłom Jegorowa. 13 sprawnych maszyn wykonało 20 lotów. Zadania realizowano nad całym przedpolem frontu. Lotnicy kontrolowali położenie atakującej na Hrubieszów 3 DPLeg., a także obserwowali postępy Armii Czerwonej. Obserwatorzy donieśli o jej marszu przez Dobrotwór i Krystynopol, a także przekroczeniu Bugu w rejonie Porycka, Kryłowa i Hrubieszowa. Przy okazji lotów rozpoznawczych eskadry wywiadowcze bombardowały napotkane oddziały. Eskadry myśliwskie ostrzeliwały przeciwnika z broni maszynowej. Polskie samoloty zrzuciły ponad $400 \mathrm{~kg}$ bomb i wystrzeliły przeszło 2,4 tys. pocisków ${ }^{61}$. Loty bojowe wykonało między innymi czterech pilotów $15 \mathrm{EM}$ (por. pil. Dziembowski, por. pil. Hendricks, ppor. pil. Lewandowski i ppor. pil. Rozmiarek). Lotnicy starali się osłonić odwrót 1 DJ płk. Rómmla ${ }^{62}$. Dwa myśliwce rzuciła do akcji $7 \mathrm{EM}$. Zadania wykonali por. pil. Jerzy Weber i por. pil. Crawford. Kilka ważnych lotów zrealizowały też eskadry wywiadowcze. Podporucznik pil. Nazimek i ppor. obs. Braun zrzucili $50 \mathrm{~kg}$ bomb. Następnie ppor. Nazimek wykonał lot z ppor. obs. Turbiakiem. Trzeci lot przeprowadzili por. pil. Bolesław Lepszy i ppor. obs. Tadeusz Janiszewski. Wyżej wymienieni lotnicy należeli do składu 5 EW. Wśród personelu 6 EW latali sierż. pil. Rączka i ppor. obs. Wojciechowski oraz plut. pil. Tissler i por. obs. Bronisław Fabian ${ }^{63}$. Praca dywizjonu była jednak utrudniona, bowiem jednostki na ziemi nie przesyłały mu meldunków sytuacyjnych ${ }^{64}$.

Kolejnym dniem intensywnych lotów bombowo-rozpoznawczych i szturmowo-rozpoznawczych był 15 sierpnia. Dzięki pracy mechaników rankiem tego dnia dywizjon dysponował liczbą 16 samolotów. Liczniejszy stan sprzętu umożliwił zrealizowanie 21 zadań w powietrzu. Załogi zrzuciły ponad $300 \mathrm{~kg}$ bomb i wystrzeliły 4 tys. pocisków. Lotnictwo zaangażowało się w ataki przede wszystkim przeciw oddziałom kawalerii i taborom w rejonie Buska, Kamionki Strumiłowej, Chołojowa i Toporowa. Już rankiem zgrupowanie 1 Armii Konnej dostrzeżono w rejonie Pobużany-Derewlany, a także pod Buskiem (tam koncentrowały się główne siły Budionnego) ${ }^{65}$. Obserwatorzy

\footnotetext{
${ }^{61}$ CAW-WBH, Szef. Lot. NDWP, sygn. I.301.12.26, Działalność III Dywizjonu Lotniczego za miesiąc sierpień 1920 r. z 1 października 1920 r., b.m., b.p.

${ }^{62}$ IV Eskadra Wielkopolska..., s. 101-102.

${ }^{63}$ CAW-WBH, D. Lot. MSWojsk., sygn. I.300.38.38, Wykaz lotów bojowych polskiego lotnictwa, b.m, b.d., b.p.

${ }^{64}$ W. Madejski, Lotnictwo w bitwie..., s. 468. Zob. też H. Mordawski, Polskie lotnictwo..., s. $314-315$.

${ }^{65}$ CAW-WBH, Szef. Lot. NDWP, sygn. I.301.12.26, Działalność III Dywizjonu Lotniczego za miesiąc sierpień 1920 r. z 1 października 1920 r., b.m., b.p. Zob. też IV Eskadra Wielkopolska..., s. 102-103; W. Madejski, Lotnictwo w bitwie..., s. 468.
} 
dostarczyli niepokojące meldunki, że Konarmia dotarła do Bugu, a linia tej rzeki była broniona tylko symbolicznie. Zaobserwowano ponadto marsz odwrotowy przez Lasy Sobole do Kamionki Strumiłowej 18 DP, która była wyznaczona do odwiezienia na północ ${ }^{66}$.

Powyższe informacje dostarczyli między innymi lotnicy 5 EW. Wykonali oni dwa ważne loty. Sierżant pil. Michał Solski leciał najpierw z por. obs. Tadeuszem Jariną, a następnie z ppor. obs. Braunem ${ }^{67}$. Skupiając się na próbie ustalenia kierunków uderzeń wojsk Budionnego ${ }^{68}$, lotnicy dokonali interesujących odkryć o nieco innym charakterze. Przykładowo wykonujący tego dnia rozpoznanie pchor. obs. Piątkowski z dowództwa dywizjonu zauważył, że kawalerzyści Konarmii po dostrzeżeniu polskiego samolotu zawracali o 180 stopni. W ten sposób chcieli wprowadzić w błąd polskich obserwatorów, a za ich pośrednictwem dowództwo całego polskiego frontu. Zjawisko to potwierdzono w kolejnych dniach ${ }^{69}$.

Tymczasem eskadry myśliwskie kontynuowały ataki o charakterze szturmowym. 7 EM ostrzeliwała i bombardowała kolumny kawalerii, oddziały piechoty, tabory i wagony kolejowe ${ }^{70}$. Poza tym kpt. pil. Corsi i por. pil. Elliot Chess przeprowadzili w parze rozpoznanie. Każdy z nich zrzucił na czerwonoarmistów po dwie bomby ${ }^{71}$.

Piloci 15 EM startowali dwa razy. Loty przedpołudniowe odbyły się bez szczególnych wydarzen ${ }^{72}$. Po południu myśliwce jednostki atakowały nieprzyjaciela w rejonie Wierzblany-Adamy-Jabłonówka-Sokole. Tam eskadrę Dziembowskiego dosięgły ciężkie straty. Z czterech wysłanych na front Fokkerów D.VII (Dziembowski, Hendricks, Bartkowiak, Rozmiarek) na macierzyste lotnisko wróciły tylko dwa. Gęste lasy na północ od Buska zapewniały czerwonoarmistom spokój, pewność siebie, a przede wszystkim dawały możliwość urządzania zasadzek na polskie samoloty. Kule z ukrytych w zalesionym terenie karabinów maszynowych raniły w obie nogi ppor. pil. Rozmiarka. Podczas wymuszonego lądowania pod Krasnem jego Fokker wpadł w rów

\footnotetext{
${ }^{66}$ CAW-WBH, Szef. Lot. NDWP, sygn. I.301.12.26, Działalność III Dywizjonu Lotniczego za miesiąc sierpień 1920 r. z 1 października 1920 r., b.m., b.p. [w meldunku podano błędnie, gdyż 18 DP znajdowała się pod Ciechanowem w składzie 5 Armii].

${ }^{67}$ CAW-WBH, D. Lot. MSWojsk., sygn. I.300.38.38, Wykaz lotów bojowych polskiego lotnictwa, b.m, b.d., b.p.

${ }^{68}$ K. A. Tarkowski, Lotnictwo polskie..., s. 100.

${ }^{69}$ W. Madejski, Lotnictwo w bitwie..., s. 468. Zob. też H. Mordawski, Polskie lotnictwo..., s. 315 .

${ }^{70}$ A. Smoliński, 1 Armia Konna..., s. 421.

${ }^{71}$ CAW-WBH, D. Lot. MSWojsk., sygn. I.300.38.38, Wykaz lotów bojowych polskiego lotnictwa, b.m, b.d., b.p.

${ }^{72}$ W. Madejski, Lotnictwo w bitwie..., s. 468.
} 
i skapotował, a pilot doznał dalszych obrażeń. Rozmiarek zmarł po 10 dniach w szpitalu we Lwowie. Na macierzyste lotnisko nie wrócił też trafiony pociskiem w cylinder Fokker por. pil. Hendricksa ${ }^{73}$. Po wylądowaniu na ziemi niczyjej pilot przedostał się do polskich linii. Wieczorem wraz $\mathrm{z}$ mechanikami eskadry próbował ewakuować samolot. Błoto, a także silny ogień nieprzyjaciela uniemożliwiły jednak realizację tego przedsięwzięcia. Wówczas por. Hendricks podpalił Fokkera. Wcześniej jednak wyciął na pamiątkę namalowany na burcie maszyny wizerunek laleczki „Bi-Ba-Bo”74.

\section{Apogeum aktywności III DL (16-17 sierpnia)}

W połowie sierpnia sytuacja Wojska Polskiego w Galicji Wschodniej stała się katastrofalna. W dniach 15-16 sierpnia bolszewicka 14 Armia sforsowała Strypę, uchwyciła przyczółek w Buczaczu i zaatakowała prawe skrzydło Frontu Południowego.

Jeszcze gorsze wiadomości spłynęły z północnego skrzydła frontu. 16 sierpnia III DL zaobserwował 1 Armię Konną na zachodnim brzegu Bugu ${ }^{75}$. Od godz. 8:25 do 9:45 swój lot realizowali por. pil. Kalkus i ppor. obs. Turbiak z 5 EW. Wykonali oni rozpoznanie na trasie Lwów-Zadwórze-Lisko-Niesłuchów-Żelechów-Streptów-Milatyn-Niesłuchów-Lwów. W Streptowie dostrzegli oddział hallerczyków. Na drodze z Milatyna do Niesłuchowa zrzucili $40 \mathrm{~kg}$ bomb na kolumnę 300 jeźdźców bolszewickich. Jeszcze przed południem załoga wykonała kolejny lot, a ppor. Turbiak mógł powtórzyć meldunek o bolszewickiej kawalerii w rejonie Niesłuchowa. Poza tym obrzucił bombami 300 kawalerzystów na południe od Kozłowa ${ }^{76}$.

Złożone przez Turbiaka raporty nie pozostawiały wątpliwości - przez Bug przeprawiły się już znaczne siły Budionnego, a kolejne kolumny i tabory przekraczały rzekę. Oddziały znajdujące się na lewym brzegu energicznie ruszyły na zachód i południowy zachód ${ }^{77}$.

${ }^{73}$ CAW-WBH, D. Lot. MSWojsk., sygn. I.300.38.38, Wykaz lotów bojowych polskiego lotnictwa, b.m, b.d., b.p. Zob. też IV Eskadra Wielkopolska..., s. 103-105; В. Кондратьев, М. Хайрулин, Авация гражданской войны, Москва 2000, s. 87; E. Lewandowski, Garść wspomnień z walk dawnej 15. myśliwskiej eskadry lotniczej (Obecnie 132) [w:] Księga Pamiątkowa 3-go Putku Lotniczego 1918-1928, Poznań 1928, s. 47; idem, Zarys historji..., s. 378-379; Ł. Łydżba, Fokkery w obronie..., s. 28; W. Madejski, Lotnictwo w bitwie..., s. 468.

${ }^{74}$ T. J. Kopański, Fokker DVII..., s. 25. Zob. też В. Кондратьев, М. Хайрулин, Авация гражданской войны..., s. 86.

${ }^{75}$ E. Lewandowski, Lotnictwo $w$ walce..., s. 32.

${ }^{76}$ W. Madejski, Lotnictwo w bitwie..., s. 470. Zob. też A. Smoliński, Udział lotnictwa..., s. 40 .

77 T. Turbiak, Walki III Dywizjonu..., s. 125. 
Przeprawa nastąpiła na odcinku od Buska do Tadania. Wkrótce Budionny zaatakował $6 \mathrm{DP}^{78}$. Lokalne kontrataki zakończyły się niepowodzeniem. Konarmia skierowała się na Żelechów z widocznym celem w postaci Lwowa. Podjazdy docierały już do Kłodna. 1 DJ i Grupa Szymańskiego znajdowały się za daleko na północ, a 13 i $12 \mathrm{DP}$ - za daleko na południe. 13 DP była oddalona od Lwowa o dwa dni drogi, a 12 DP - o cztery. Tymczasem nieprzyjaciel był w stanie dotrzeć do stolicy Galicji w ciągu 24 godz. Jedynym oparciem dla 6 DP był w tym czasie detachement rtm. Romana Abrahama ${ }^{79}$.

Czas potrzebny na przegrupowania mogła dać tylko zdecydowana akcja III DL. Major pil. Faunt le Roy największe szanse powodzenia dostrzegł w całodziennych nalotach nękających. Kilkanaście samolotów dywizjonu miało od świtu do zmierzchu $\mathrm{z}$ wysokości $50 \mathrm{~m}$ atakować $\mathrm{z}$ karabinów maszynowych kolumny 1 Armii Konnej ${ }^{80}$. W dniu 16 sierpnia dywizjon dysponował liczbą 18 bądź 19 sprawnych samolotów ${ }^{81}$.

Poza porannymi startami z podkomendnych Kalkusa latali jeszcze między innymi por. pil. B. Lepszy i ppor. obs. Janiszewski, a także ppor. pil. Nazimek i ppor. obs. Braun. Każda z tych załóg zrzuciła po jednej dziesięciokilogramowej bombie. Armia Czerwona była tak blisko Lwowa, że loty trwały tylko godzinę. Nie tracono już czasu na bezproduktywne przeloty, a przy tym można było zabrać więcej bomb. Przykładowo podczas drugiego tego dnia lotu por. pil. B. Lepszy i ppor. obs. Janiszewski zrzucili na Konarmię 10 dwunastokilogramowych bomb. Identyczny ładunek ten sam obserwator zabrał podczas trzeciego lotu, który wykonał z ppor. pil. Nazimkiem. Lot przeprowadzili też sierż. pil. Jan Ryba i por. obs. Adam Paleolog ${ }^{82}$.

${ }^{78}$ Komunikat operacyjny nr 11 z 17 sierpnia 1920 r. [w:] Bitwa lwowska..., cz. II, s. 518-519. Zob. też L. Wyszczelski, Wojna polsko-rosyjska 1919-1920, t. 2, Warszawa 2010, s. 366-368. Meldunek o przekroczeniu Bugu jeszcze tego samego dnia sztab frontu przekazał podległym jednostkom; zob. Ku czci poległych lotników. Księga pamiątkowa, pod red. M. Romeyki, Warszawa 1933, s. 218.

${ }^{79}$ Komunikat operacyjny $n r 10$ z 16 sierpnia 1920 r. [w:] Bitwa lwowska..., cz. II, s. 499-500. Zob. W. Madejski, Lotnictwo w bitwie..., s. 469-470.

${ }^{80}$ E. Lewandowski, Zarys historji..., s. 377-378. Zob. też T. J. Kopański, 7 Eskadra Myśliwska..., s. 102-103; A. Olejko, Działania lotnicze..., s. 128.

${ }^{81} \mathrm{O} 18$ gotowych do lotu maszynach mowa w dokumencie zatytułowanym: Działalność III Dywizjonu Lotniczego za miesiąc sierpień 1920 r. (zob. CAW-WBH, Szef. Lot. NDWP, sygn. I.301.12.26, 1 października, b.m., b.p.). Liczbę 19 sprawnych samolotów podaje Komunikat operacyjny Frontu Południowego z 17 sierpnia 1920 roku [w:] Bitwa lwowska..., cz. II, s. 519. Turbiak natomiast wymienił liczbę 16 sprawnych maszyn (zob. idem, Walki III Dywizjonu..., s. 126). W późniejszej historiografii liczbę tę powtórzył m.in. Krzysztof Tarkowski (zob. idem, Lotnictwo polskie..., s. 101).

${ }^{82}$ CAW-WBH, D. Lot. MSWojsk., sygn. I.300.38.38, Wykaz lotów bojowych polskiego lotnictwa, b.m, b.d., b.p. 
Podporucznik pil. Bartkowiak z 15 EM wystartował z zadaniem zaatakowania nieprzyjaciela na zachodnim brzegu Bugu. Leciał od Lwowa, przez Busk, Wierzblany, Pobużany, Streptów, Żelechów, Rzepniów, Kozłów, Niesłuchów, Jakimów i Dziedziłów, a następnie wylądował na macierzystym lotnisku. Podczas lotu zaobserwował i zaatakował nieprzyjaciela w rejonie Miroczyna, Pobużan, Rakobutów, Rzepniowa i Żelechowa. Wykrył też wrogie baterie na północ od Buska i we wschodniej części Pobużan, a także pojedyncze działa, samochody pancerne i mniejsze oddziały nieprzyjaciela w rejonie Buska, stacji kolejowej Krasne, Niesłuchowa, Milatyna, Kozłowa i Żuratyna. Realizując zadanie, Bartkowiak dwukrotnie lądował po drodze. Na północ od Krasnego oraz na południe od Buska pilot przekazał polskim bateriom artylerii meldunki o ruchach 1 Armii Konnej ${ }^{83}$.

Od rana po dwa loty wykonali jeszcze dowódca 15 EM por. pil. Dziembowski oraz jego podkomendny ppor. pil. Lewandowski. Piloci Fokkerów D.VII wylecieli z poleceniem przeprowadzenia ataku na nieprzyjacielską kawalerię, przeprawiającą się przez Bug w rejonie Busk-Derewlany. Na drodze pomiędzy Jabłonówką a Buskiem oficerowie ostrzelali z karabinów maszynowych kolumnę około 1 tys. jeźdźców oraz liczne tabory. Pod Pobużanami rozproszyli czerwonoarmistów starających się naprawić most. Lotnicy dostrzegli ponadto przeprawę pod Rakobutami, a na północny wschód od Żelechowa byli świadkami udanego ataku bombowego innego polskiego samolotu na kolumnę 300 kawalerzystów ${ }^{84}$.

Spośród pilotów 7 EM im. T. Kościuszki latali tego dnia kpt. pil. Corsi (zrzucił na nieprzyjaciela dwie bomby) ${ }^{85}$, a także por. pil. Weber, który zaatakował bronioną kolumnę taborową, a przy tym rzucił dwie bomby na wieś Kupcze. Z powodu przegrzewającego się silnika przerwał dalszy lot i powrócił na Lewandówkę

Po południu lot rozpoznawczy wykonali też sierż. pil. Rączka i por. obs. Fabian z 6 EW. Między Łodyną Nową a Horpinem byli świadkami toczonych walk, natomiast na południe od Żelechowa dostrzegli kolumnę około 1 tys. bolszewickich jeźdźców. W rejonie Milatyna natrafili na kolejnych 200.

${ }^{83}$ W. Madejski, Lotnictwo w bitwie..., s. 471. Zob. IV Eskadra Wielkopolska..., s. 107-108; A. Smoliński, Udział lotnictwa..., s. 40.

${ }^{84}$ W. Madejski, Lotnictwo w bitwie..., s. 471-472. Zob. IV Eskadra Wielkopolska..., s. 108; A. Smoliński, Udział lotnictwa..., s. 40.

${ }^{85}$ CAW-WBH, D. Lot. MSWojsk., sygn. I.300.38.38, Wykaz lotów bojowych polskiego lotnictwa, b.m, b.d., b.p.

${ }^{86}$ W Wykazie lotów bojowych polskiego lotnictwa (zob. ibidem) znajdują się wzmianki o locie Webera i Corsiego, lecz informacja o bombach widnieje tylko przy nazwisku amerykańskiego ochotnika. Nie można wykluczyć, że Madejski (W. Madejski, Lotnictwo w bitwie..., s. 472) omyłkowo zaliczył Weberowi bombardowanie autorstwa Corsiego. 


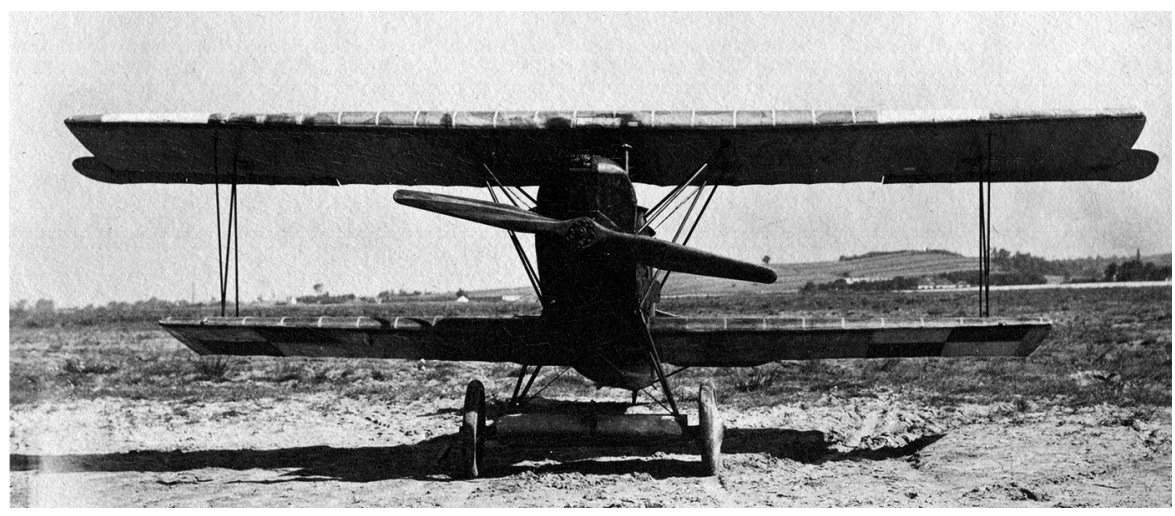

Fot. 2. Samolot myśliwski Fokker D.VII (nr niemiecki 1075, nr Stacji Lotniczej w Ławicy 502/18). Od grudnia 1919 r. wykorzystywany w 4 Wielkopolskiej Eskadrze Bojowej (15 Eskadrze Myśliwskiej). Uwieczniony na zdjęciu egzemplarz brał udział w walkach z 1 Armią Konną na przedpolach Lwowa

Źródło: zdjęcie ze zbiorów ks. Roberta Kulczyńskiego SDB

Po drodze por. Fabian zrzucił meldunek rtm. Abrahamowi ${ }^{87}$. W czasie lotu załoga zaatakowała nieprzyjaciela sześcioma bombami ${ }^{88}$.

W dwóch lotach rozpoznawczych uczestniczył ppor. obs. Wojciechowski z 6 EW. Podczas pierwszego za sterami samolotu zasiadł sierż. pil. Rączka, a w czasie drugiego - plut. pil. Tissler ${ }^{89}$.

Wieczorem plut. pil. Tissler wykonał jeszcze jeden lot. Tym razem towarzyszył mu por. obs. Kubala z dowództwa dywizjonu. W drobiazgowym meldunku Kubali znalazły się informacje o rozlicznych taborach i baterii artylerii od Srok Lwowskich do Lwowa oraz w rejonie Żydatyczowa. Pod Niesłuchowem obserwator zauważył ukryty oddział kawalerii w sile 800 jeźdźców, między Nahorcami Małymi a Żelechowem kolejny taki oddział, a w Nahorcach Małych - o połowę mniejszy. Silniejsze oddziały i większe tabory dostrzegł jeszcze w Streptowie, Rzepniowie, Milatynie i na zachód od Żuratyna. Na południe od Kozłowa widział 200 wozów rozproszonych po polach, co było skutkiem ataku innego polskiego samolotu. Na północ od Duniowa zaobserwował jeszcze pół tys. kawalerzystów po przeprawie przez rzekę Dumnicę. Kolejne oddziały i tabory zauważył pod Kędzierzawcami i w rejonie Niesłuchowa. Pod miejscowością Ubinie widział walkę czerwonoarmistów z polską kawalerią. Zakończyła się ona odwrotem Polaków na Zadwórze. Na południe od miejscowości Nowosiółki Liskie załoga powstrzymała nacierających jeźdźców ogniem broni maszynowej. Pod Streptowem i Niesłuchowem Tissler

\footnotetext{
${ }^{87}$ W. Madejski, Lotnictwo w bitwie..., s. 472.

${ }^{88}$ CAW-WBH, D. Lot. MSWojsk., sygn. I.300.38.38, Wykaz lotów bojowych polskiego lotnictwa, b.m, b.d., b.p.
}

${ }^{89}$ Ibidem. 


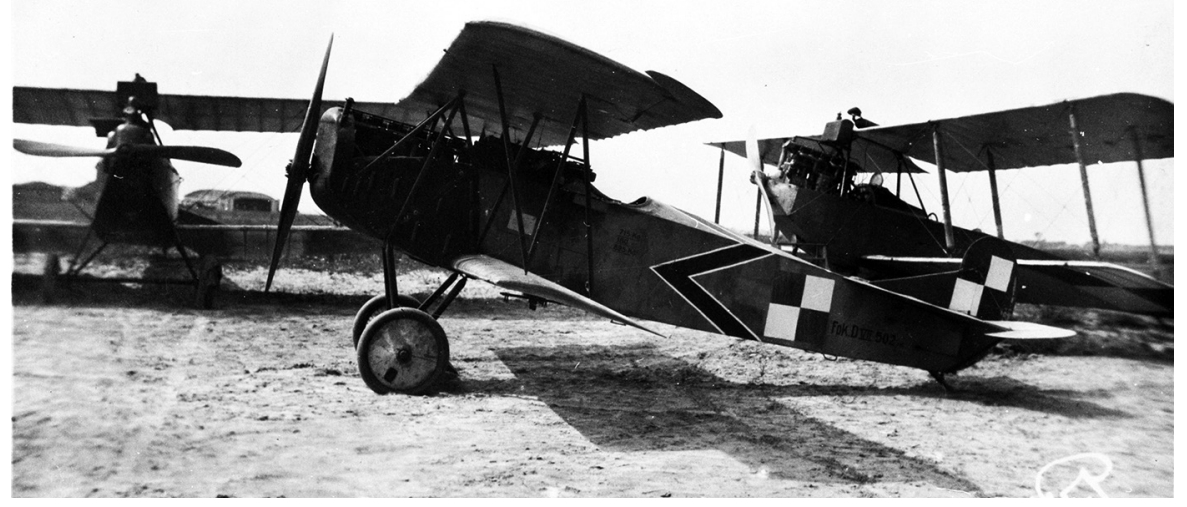

Fot. 3. Uwieczniony na poprzednim zdjęciu samolot Fokker D.VII. W tle stoją wywiadowcze Hansa-Brandenburgi C.I. W czasie wojny polsko-bolszewickiej były one wytwarzane przez warsztaty lotnicze we Lwowie. Eksploatowała je głównie 6 Eskadra Wywiadowcza Żródło: zdjęcie ze zbiorów Muzeum Lotnictwa Polskiego w Krakowie

i Kubala zauważyli też baterie artylerii. Meldunek z obserwacji przekazali zarówno do sztabu armii, jak i zrzucili polskiemu oddziałowi w Zadwórzu ${ }^{90}$. Nie był to jedyny cenny raport por. Kubali w tym dniu. Na podstawie jego meldunków sztab 6 Armii ustalił, że nieprzyjacielska kawaleria przeprawiała się przez Bug także pod Pobużanami i intensywnie posuwała się naprzód na Kozłów i Lisko ${ }^{91}$.

Wieczorem jeszcze jeden lot rozpoznawczy wykonała załoga z dowództwa dywizjonu. Za sterami zasiadł mjr pil. Faunt le Roy, a towarzyszył mu pchor. obs. Piątkowski. Zauważyli oni prące na zachód masy kawalerii ${ }^{92}$.

W sumie 16 sierpnia III DL wykonał 58 zadań w powietrzu, zrzucił 3,8 t bomb i wystrzelił ponad 5,8 tys. pocisków z karabinów maszynowych. Skuteczność ataków zwiększył fakt, że 1 Armia Konna przemieszczała się tego dnia w terenie bezleśnym. Polskie samoloty otrzymały wiele trafień, ale żadne ważniejsze elementy płatowców ani silników nie zostały uszkodzone. Kule ominęły również lotników. Akcje lotnicze znacząco spowolniły kawalerię, ale nie przyniosły pełnego sukcesu, bowiem brakowało współpracy ze strony wojsk na ziemi ${ }^{93}$. Spośród 58 wykonanych lotów

\footnotetext{
${ }^{90}$ W. Madejski, Lotnictwo w bitwie..., s. 472-473. Zob. też: A. Smoliński, Udział lotnictwa..., s. 41.

${ }^{91}$ CAW-WBH, Szef. Lot. NDWP, sygn. I.301.12.26, Działalność III Dywizjonu Lotniczego za miesiąc sierpień 1920 r. z 1 października 1920 r., b.m., b.p.

${ }^{92}$ W. Madejski, Lotnictwo w bitwie..., s. 472. Zob. też A. Smoliński, Udział lotnictwa..., s. 41.

${ }^{93}$ CAW-WBH, Szef. Lot. NDWP, sygn. I.301.12.26, Działalność III Dywizjonu Lotniczego za miesiąc sierpień 1920 r. z 1 października 1920 r., b.m., b.p. Zob. też IV Eskadra
} 
piętnaście było udziałem pilotów 7 EM. Pięć razy Konarmię atakował por. pil. Weber, a po cztery por. pil. Chess i ppor. pil. Seńkowski. Dwa zadania w powietrzu wykonał kpt. pil. Corsi. Z powodu choroby dowódca eskadry por. pil. Crawford przez kilka dni nie latał. Trzy zadania w powietrzu przeprowadził za to dowódca dywizjonu mjr. pil. Faunt le Roy ${ }^{94}$. Po cztery razy przeciw nieprzyjacielskiej kawalerii startowali por. pil. Dziembowski i ppor. pil. Lewandowski z $15 \mathrm{EM}^{95}$.

Piloci i obserwatorzy byli na granicy wycieńczenia fizycznego i psychicznego. Wyczerpywały ich loty w niespokojnym powietrzu tuż nad rozgrzaną sierpniowym słońcem ziemią. Do tego dochodziły ciągłe zmiany ciśnienia wywołane gwałtownym nurkowaniem do ataku z broni maszynowej. Nie można też zapominać o hałasie silnika oraz trzasku broni ręcznej i maszynowej, $\mathrm{w}$ rezultacie czego wieczorem lotnicy już ledwie słyszeli i porozumiewanie się wymagało krzyków ${ }^{96}$.

Personel latający mógł nieco wypocząć nocą. Mechanicy natomiast wykonywali wówczas ciężką pracę. Dzięki niej kolejnego dnia dywizjon dysponował 19 samolotami. Przełożyło się to na wykonanych 17 sierpnia aż 67 lotów bojowych, w czasie których zrzucono 3,9 t bomb i wystrzelono blisko 11 tys. pocisków ${ }^{97}$.

Poranny lot rozpoznawczy dostarczył wiadomości o koncentracji jazdy i taborów w rejonie Lisko-Kędzierzawce-Kozłów-Milatyn-NiesłuchówŻelechów. Dostrzeżono też własne oddziały, atakujące na północ od linii kolejowej Zadwórze-Krasne. Sztab Frontu Południowego oczekiwał skupienia akcji lotniczej na północ od drogi żelaznej Krasne-Busk, we wsiach LiskoKędzierzawce, a także ogólnego spowalniania marszu 1 Armii Konnej ${ }^{98}$.

Wielkopolska..., s. 107. W źródłach pojawia się też informacja o 49 przeprowadzonych lotach; zob. Komunikat operacyjny Frontu Poludniowego z 17 sierpnia 1920 r. [w:] Bitwa lwowska..., cz. II, s. 519; T. Turbiak, Walki III Dywizjonu..., s. 128. W historiografii liczbę 49 lotów bojowych podchwycił np. Aleksander Smoliński (zob. idem, Udział lotnictwa..., s. 40).

${ }_{94}$ T. J. Kopański, 7 Eskadra Myśliwska..., s. 101-103. Nieco inaczej przedstawili to Robert Karolevitz i Ross Fenn, którzy zaliczyli wprawdzie pięć lotów bojowych Weberowi i trzy Faunt le Roy, ale napisali też o czterech akcjach lotniczych Corsiego (zob. eidem, Dlug honorowy. Amerykańscy piloci Eskadry Myśliwskiej im. Kościuszki w wojnie polsko-bolszewickiej 1919-1920, Warszawa 2005, s. 189-190). Zdaniem Aleksandra Smolińskiego 7 EM wykonała tego dnia 18 zadań w powietrzu (idem, 1 Armia Konna..., s. 421). Prawdopodobnie liczone są tu loty mjr. pil. Faunt le Roy.

${ }_{95}$ W. Madejski, Lotnictwo w bitwie..., s. 475, 479, 484.

${ }^{96}$ T. Turbiak, Walki III Dywizjonu..., s. 128.

${ }^{97}$ CAW-WBH, Szef. Lot. NDWP, sygn. I.301.12.26, Działalność III Dywizjonu Lotniczego za miesiąc sierpień 1920 r. z 1 października 1920 r., b.m., b.p. Zob. też T. J. Kopański, 7 Eskadra Myśliwska..., s. 103. Według innej wersji 19 maszyn dywizjonu wykonało 69 lotów bojowych. Zob. Ksiegga Pamiątkowa 3-go..., s. 25; K. A. Tarkowski, Lotnictwo polskie..., s. 101.

${ }_{98}$ T. Turbiak, Walki III Dywizjonu..., s. 128-129. 
Zgodnie $\mathrm{z}$ poleceniem dywizjon atakował Konarmię $\mathrm{w}$ rejonie wsi Lisko-Kędzierzawce, pod Kozłowem, Milatynem, Niesłuchowem i Żelechowem. Miejsca postoju nieprzyjaciela były ostrzeliwane z broni maszynowej i obrzucane bombami. Lotnicy wspierali też własną piechotę na północ od linii kolejowej Krasne-Zadwórze ${ }^{99}$. Właśnie pod tą ostatnią miejscowością sytuacja na ziemi stała się krytyczna. Wystrzeliwszy ostatnie pociski i zrzuciwszy wszystkie bomby, lotnicy starali się rykiem silników rozpraszać oddziały wrogiej kawalerii ${ }^{100}$. Ceną zapłaconą za brawurowe ataki było pięć niezdolnych do lotów maszyn. Wśród lotników nie było strat ${ }^{101}$. Nie obroniono wprawdzie Zadwórza, ale powstrzymano dalszy marsz kawalerii. Dzięki temu polski pociąg pancerny mógł wycofać się z Krasnego do Barszczowic. Ponadto Dywizjon blokował przeprawę Armii Czerwonej przez Pełtew. Lotnictwo zasłużyło się też dla obrońców Kamionki Strumiłowej. Powstrzymano tam atak Budionnego i umożliwiono własnej piechocie oderwanie się od nieprzyjaciela $^{102}$. Czas na zajęcie nowych pozycji obronnych dał polskim oddziałom między innymi plut. pil. Tissler z $6 \mathrm{EW}^{103}$. Towarzyszył mu prawdopodobnie ppor. obs. Tarasiewicz, z którym Tissler przeprowadził tego dnia trzy zadania w powietrzu. Kolejne trzy loty wykonał por. obs. Fabian. Dwa razy poleciał z sierż. pil. Rączką, a raz - z chor. pil. Cagaškiem. Za pierwszym razem obserwator zrzucił sześć bomb, za drugim - siedem, a za trzecim cztery. Dwa zadania w powietrzu wykonała też mieszana załoga ppor. pil. Seńkowski (7 EM) i por. obs. Leonard Lepszy (6 EW). Łącznie zrzucili oni na nieprzyjaciela 10 bomb $^{104}$.

Szereg zadań bojowych zrealizowała 5 EW. Dwa loty przeprowadzili dowódca eskadry por. pil. Kalkus i ppor. obs. Turbiak, a trzy - ppor. pil.

${ }^{99}$ E. Lewandowski, Zarys historji..., s. 379. Zob. też Księga Pamiątkowa 3-go..., s. 25; E. Lewandowski, Lotnictwo $w$ walce..., s. 32.

${ }^{100}$ Księga Pamiątkowa 3-go..., s. 25. Turbiak pisał: „Widząc grozę położenia ustępujących krok za krokiem oddziałów polskich, rozzuchwaleni bezkarnością wczorajszych ataków lotnicy, po wyrzuceniu ostatniej bomby, wystrzeleniu ostatniego naboju z karabinu maszynowego, szumem skrzydeł rozpędzali maszerujące po drogach i przeprawiające się przez rzeczułki oddziały kawalerji bolszewickiej. To też około godziny 16-tej wróciło na lotnisko, ledwo kilka postrzelanych samolotów, niezdatnych do dalszej walki, inne naprędce łatały dziury". T. Turbiak, Walki III Dywizjonu..., s. 129.

\section{Ibidem.}

102 CAW-WBH, Szef. Lot. NDWP, sygn. I.301.12.26, Działalność III Dywizjonu Lotniczego za miesiąc sierpień 1920 r. z 1 października 1920 r., b.m., b.p. Zob. też IV Eskadra Wielkopolska..., s. 109.

${ }^{103}$ J. Zieliński, W. Wójcik, Lotnicy Kawalerowie Orderu Wojennego Virtuti Militari 1918-1920, Warszawa-Toruń 2005, s. 204.

${ }^{104}$ CAW-WBH, D. Lot. MSWojsk., sygn. I.300.38.38, Wykaz lotów bojowych polskiego lotnictwa, b.m, b.d., b.p. 


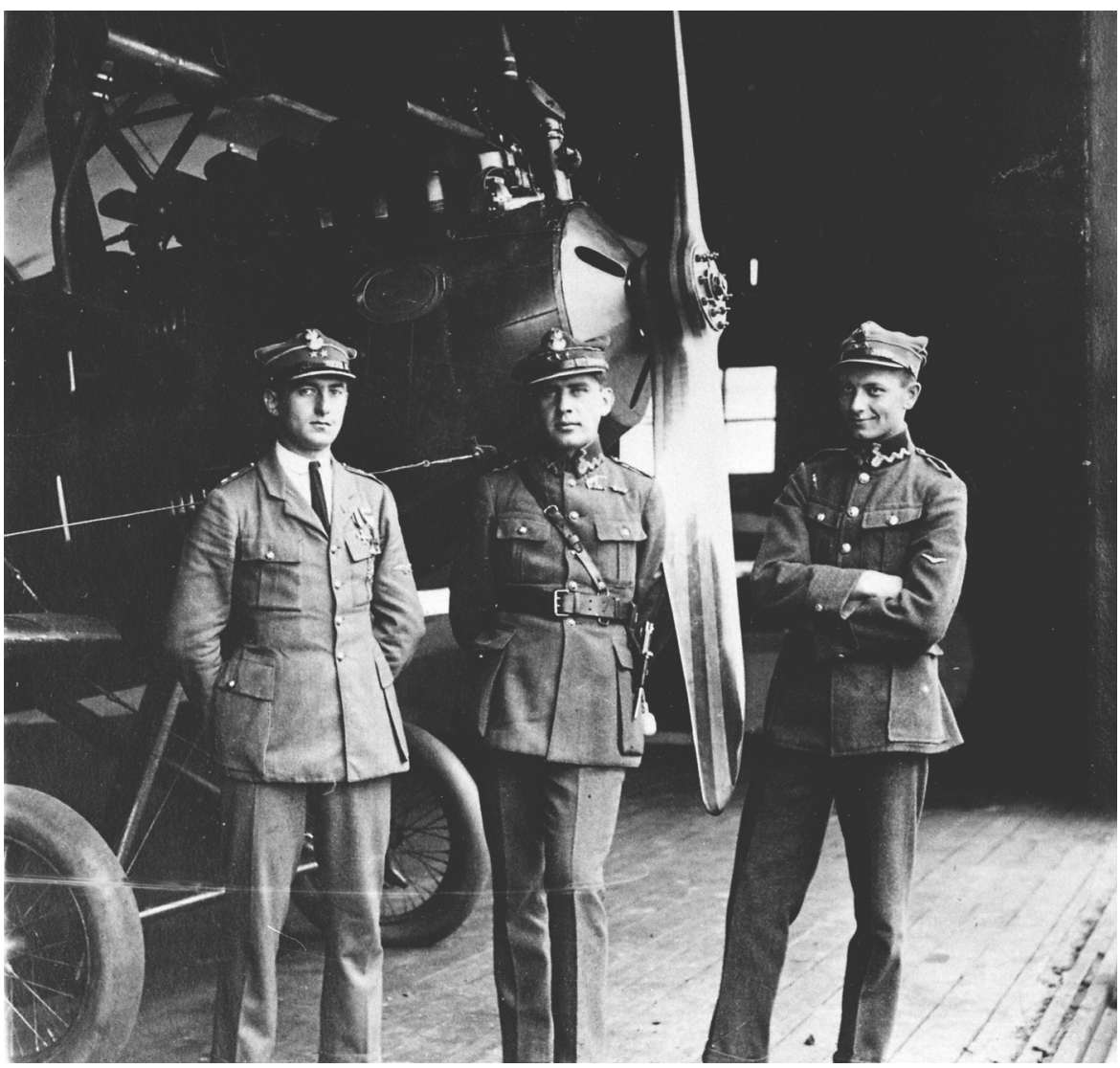

Fot. 4. Lotnicy III Dywizjonu Lotniczego, od lewej: obserwator 6 Eskadry Wywiadowczej por. Franciszek Piniński, dowódca 5 Eskadry Wywiadowczej por. pil. Władysław Kalkus i obserwator 6 Eskadry Wywiadowczej por. Józef Wojciechowski. W tle samolot LVG C.V. Źródło: zdjęcie ze zbiorów Muzeum Lotnictwa Polskiego w Krakowie

Nazimek i ppor. obs. Braun. Nazimek poleciał jeszcze z por. obs. Jariną. Zrzucili oni wówczas 10 bomb. Porucznik Jarina wykonał też lot $\mathrm{z}$ sierż. pil. Solskim. Zabrał wtedy cztery bomby. Sierżant Solski poleciał także z por. obs. Władysławem Popiel-Sulimą. Temu ostatniemu w kolejnym locie towarzyszył dowódca lwowskiego III Ruchomego Parku Lotniczego - por. pil. Eugeniusz Roland ${ }^{105}$.

Wielką rolę w działaniach powietrznych tego dnia odegrały eskadry myśliwskie. Kapitan pil. Corsi z 7 EM swój pierwszy start wykonał już tuż po godz. 4:00, a w sumie tego dnia zrealizował cztery loty. Za każdym razem amerykański ochotnik zrzucił po dwie bomby. Jeszcze więcej, bo pięć zadań $\mathrm{w}$ powietrzu wykonał por. pil. Weber ${ }^{106}$. W czasie każdego $\mathrm{z}$ nich zrzucił

\footnotetext{
${ }^{105}$ Ibidem.
}

${ }^{106}$ W. Madejski, Lotnictwo w bitwie..., s. 475. Zob. też IV Eskadra Wielkopolska..., s. 110. 
na Konarmię po dwie bomby ${ }^{107}$. Seńkowski poza lotami z por. obs. L. Lepszym przeprowadził dwa kolejne zadania, Chess wykonał trzy loty (jeden w parze z Corsim), w czasie których zrzucił łącznie sześć bomb. Dowódca dywizjonu, mjr Faunt le Roy startował dwa razy ${ }^{108}$.

Po cztery loty bojowe wykonali: por. pil. Dziembowski, por. pil. Hendricks oraz ppor. pil. Lewandowski z 15 EM. Począwszy od godz. 9:00 przez 10 godzin niemal bez przerwy w powietrzu znajdował się co najmniej jeden $\mathrm{z}$ nich. Dziembowski skupił się na atakach w rejonie Buska ${ }^{109}$. Podporucznik Lewandowski przeprowadził rozpoznanie wzdłuż linii kolejowej ze Lwowa do Krasnego, zaatakował oddział kawalerii w rejonie miejscowości Nowosiółki Liskie, a także ostrzelał baterię w rejonie wsi Horpin. Pod Horpinem nieprzyjacielska kula uszkodziła układ chłodzenia w jego Fokkerze. Silnik bez wody się zatarł, ale pilotowi udało się wylądować w polu. Samolot ewakuowano do Lwowa ${ }^{110}$. Porucznik Hendricks na północ od zamku w Milatynie kilkukrotnie z 30 metrów ostrzelał z broni maszynowej grupę około 1 tys. jeźdźców. Jego Fokker został wówczas trafiony kilkoma kulami. Lecąc stamtąd na południe, pilot zauważył pod Zadwórzem nieprzyjacielskie tyraliery atakujące polskie pozycje. Zniżając się do $10 \mathrm{~m}$, odparł atak, po czym wylądował i złożył raport ${ }^{111}$.

W dowództwie 6 Armii stwierdzono, że to właśnie ataki szturmowe i bombowe z 17 sierpnia pozwoliły odwrócić beznadziejne, zdawałoby się, położenie Lwowa ${ }^{112}$. Tego dnia 1 Armia Konna podeszła do miasta na zaledwie $10 \mathrm{~km}^{113}$. Niezależnie od opisanych wyżej spektakularnych akcji dywizjon przekazal jeszcze rozkazy dla 12 i $13 \mathrm{DP}^{114}$.

${ }^{107}$ CAW-WBH, D. Lot. MSWojsk., sygn. I.300.38.38, Wykaz lotów bojowych polskiego lotnictwa, b.m, b.d., b.p.

${ }^{108}$ Ibidem. Zob. też T. J. Kopański, 7 Eskadra Myśliwska..., s. 102-104.

109 W. Madejski, Lotnictwo w bitwie..., s. 475. Zob. też IV Eskadra Wielkopolska..., s. 110.

${ }^{110}$ Komunikat operacyjny Frontu Południowego z 17 sierpnia 1920 r. [w:] Bitwa lwowska..., cz. II, s. 518-519; zob. też IV Eskadra Wielkopolska..., s. 113-114; E. Lewandowski, Lotnictwo $w$ walce..., s. 32-33; idem, Zarys historji..., s. 379; W. Madejski, Lotnictwo w bitwie..., s. 474 . Komunikat operacyjny nie jest do końca precyzyjny. Nie można wykluczyć, że lot miał miejsce 18 sierpnia (tak sugeruje np. zespół ks. Roberta Kulczyńskiego SDB).

${ }^{111}$ J. Zieliński, W. Wójcik, Lotnicy Kawalerowie..., s. 64. Zob. też IV Eskadra Wielkopolska..., s. 112-113. W historiografii polskiego lotnictwa, opierając się na wniosku odznaczeniowym dla Hendricksa, wydarzenie to datuje się na 18 sierpnia. Było to jednak już po zajęciu przez bolszewików Zadwórza. Bój o tę miejscowość miał miejsce 17 VIII 1920 r. i to wówczas Hendricks musiał działać w tamtym rejonie.

\footnotetext{
${ }^{112}$ W. Madejski, Lotnictwo w bitwie..., s. 475-476. Zob. też Ku czci.., s. 223.

${ }^{113}$ K. A. Tarkowski, Lotnictwo polskie..., s. 101.

${ }^{114}$ W. Madejski, Lotnictwo w bitwie..., s. 477.
} 


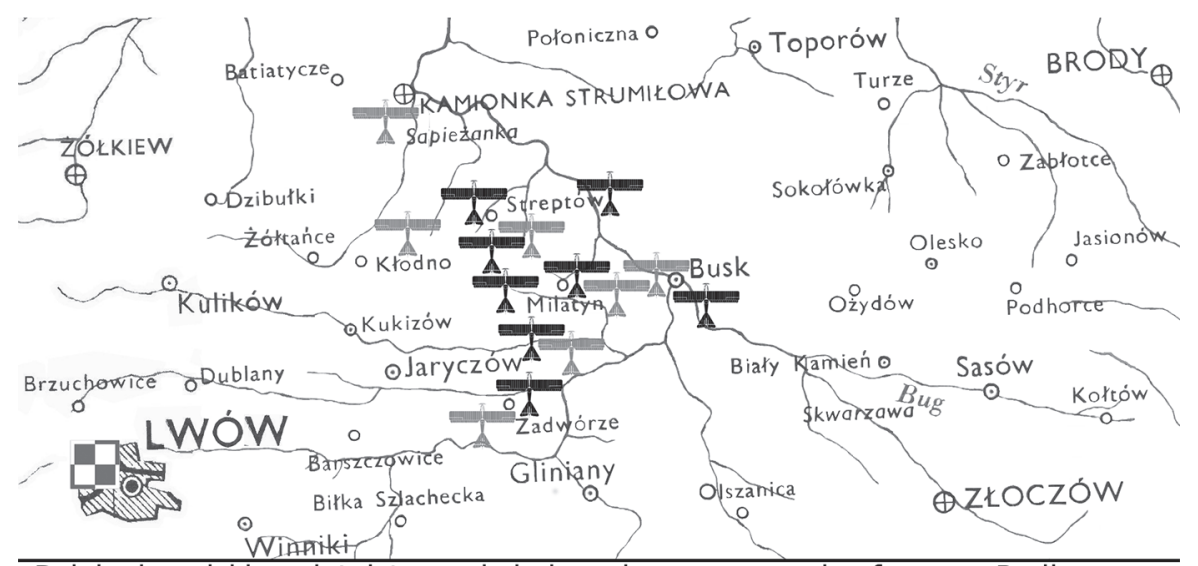

Działania polskiego lotnictwa w kulminacyjnym momencie ofensywy Budionnego na Lwów (16-17 sierpnia 1920 roku).

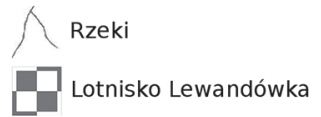

Ważniejsze akcje III. Dywizjonu Lotniczego w dniu 16 sierpnia.
Ważniejsze akcje III. Dywizjonu Lotniczego w dniu 17 sierpnia.

Wykorzystano „Mapę Polski i krajów ościennych. Warszawa-Lwów” z 1943 r. Oryginał mapy dostępny w internecie: http://maps.mapywig.org/m/WIG_maps/series/M1/MPIKO_1M_Arkusz_SE_WARSZAWA-LWOW_1943_600dpi.jpg

Tymczasem pojawiła się szansa na zagrodzenie drogi „powodzi” kawalerii. Do świtu 18 sierpnia 5 DP miała się skoncentrować wzdłuż osi Kamionka Strumiłowa-Dzibułki, a 6 DP - na północny wschód od miejscowości Prusy. Do dyspozycji dywizji oddano między innymi dostępne samochody ciężarowe $\mathrm{e}^{115}$.

\section{Zwycięstwo (18-19 sierpnia)}

Przechodząc do opisu działań III DL w dniu 18 sierpnia, trzeba zwrócić uwagę na sprzeczność informacji zawartych w źródłach. W części z nich pada informacja o 72 lotach bojowych ${ }^{116}$, a w innych - o $28^{117}$. Starsza literatura

\footnotetext{
${ }^{115}$ Rozkaz operacyjny nr 5 dowództwa Frontu Południowego z 17 sierpnia 1920 r. [w:] Bitwa lwowska..., cz. II, s. 521.

${ }^{116}$ CAW-WBH, Szef. Lot. NDWP, sygn. I.301.12.26, Wyciągi z radiodepesz nieprzyjacielskich przejętych przez własne wojska z 1 września 1920 roku, b.m., b.p.; Rozkaz pochwalny gen. por. Roberta Lamezan-Salinsa dla III Dywizjonu Lotniczego z 11 września 1920 roku, b.m., b.p.; T. Turbiak, Walki III Dywizjonu..., s. 129; E. Lewandowski, Zarys historji..., s. 379; idem, Lotnictwo $w$ walce..., s. 32-33.

${ }^{117}$ CAW-WBH, Szef. Lot. NDWP, sygn. I.301.12.26, Działalność III Dywizjonu Lotniczego za miesiąc sierpień 1920 r. z 1 października 1920 r., b.m., b.p.
} 
pisała zasadniczo o $72^{118}$, natomiast autorzy nowszych prac optują za mniejszą liczbą lotów ${ }^{119}$.

Mgła i niska podstawa chmur, a także wycieńczenie personelu i zużycie sprzętu każą traktować tę drugą wersję jako bardziej prawdopodobną. 18 sierpnia Dywizjon miał 18 sprawnych maszyn, które wykonywały stosunkowo krótkie loty, prowadzone w najbliższych okolicach Lwowa. Zrzucono ponad $430 \mathrm{~kg}$ bomb i wystrzelono 3,5 tys. sztuk amunicji ${ }^{120}$.

Przeprowadzony rankiem lot rozpoznawczy dostarczył informacje o obecności nieprzyjaciela na północny wschód od Lwowa (w Żółtańcach, Kłodnie i Czestyniu) oraz na wschód od Lwowa (na południe od stacji kolejowej Zadwórze, w rejonie wsi Połonice, Zuchorzyce oraz folwarku Połonice Bohdanówka). Jeszcze rankiem Dywizjon atakował nieprzyjaciela kryjącego się w lasach w tym drugim rejonie. Maszerujące leśnymi dróżkami kolumny kawalerii nie miały miejsca na rozproszenie się i poniosły duże straty. Po południu oznaczone biało-czerwonymi szachownicami samoloty zaatakowały nieprzyjaciela na drodze przebiegającej przez wsie Wisłoboki-Remenów-Żółtańce. Miało to ułatwić zaplanowany na następny dzień atak polskiej kawalerii od strony Żółkwi ${ }^{121}$. W rejonie Zadwórza szczególnie odznaczył się ppor. obs. Tarasiewicz z 6 EW, który tego ranka celnie rzuconą bombą zniszczył całą kolumnę amunicyjną ${ }^{122}$. Tarasiewiczowi towarzyszył plut. pil. Tissler. Ogółem zrzucili oni sześć bomb. Z personelu $6 \mathrm{EW}$ zadanie w powietrzu wykonali też sierż. pil. Rączka i por. obs. L. Lepszy, którzy zużyli podczas lotu dziewięć bomb ${ }^{123}$.

Nie próżnowała 5 EW. Loty przeprowadzili sierż. pil. Ryba i ppor. obs. Turbiak, ppor. pil. Nazimek i ppor. obs. Braun oraz sierż. pil. Solski

${ }^{118}$ Zob. Ksiegga Pamiątkowa 3-go..., s. 25; Ku czci..., s. 222-223; A. Smoliński, Udziat lotnictwa..., s. 42-43.

119 Zob. IV Eskadra Wielkopolska..., s. 112; T. J. Kopański, 7 Eskadra Myśliwska..., s. 103-105.

${ }^{120}$ CAW-WBH, Szef. Lot. NDWP, sygn. I.301.12.26, Działalność III Dywizjonu Lotniczego za miesiąc sierpień 1920 r. z 1 października 1920 r., b.m., b.p. Pojawiają się też informacje o 14 sprawnych samolotach tego dnia (zob. T. Turbiak, Walki III Dywizjonu..., s. 130; Ku czci..., s. 223).

${ }^{121}$ Komunikat operacyjny Frontu Południowego z 17 sierpnia 1920 r. [w:] Bitwa lwowska..., cz. II, s. 518-519; zob. też IV Eskadra Wielkopolska..., s. 113-114; Księga Pamiątkowa 3-go..., s. 25; E. Lewandowski, Lotnictwo w walce..., s. 32-33; idem, Zarys historji..., s. 379; W. Madejski, Lotnictwo w bitwie..., s. 474; K. A. Tarkowski, Lotnictwo polskie..., s. 101, 103; T. Turbiak, Walki III Dywizjonu..., s. 129.

122 T. Turbiak, Walki III Dywizjonu..., s. 129-130. Zob. też: 2. Pułk Lotniczy. 1919-1929, praca zbiorowa, Kraków 1929, s. 20; A. Olejko, Działania lotnicze..., s. 129 i przypis; K. A. Tarkowski, Lotnictwo polskie..., s. 103.

${ }^{123}$ CAW-WBH, D. Lot. MSWojsk., sygn. I.300.38.38, Wykaz lotów bojowych polskiego lotnictwa, b.m, b.d., b.p. 
i ppor. obs. Janiszewski. Sierżant Solski wykonał też zadanie z por. obs. Jarinąa ${ }^{124}$. Spośród pilotów 7 EM zadania w powietrzu zrealizowali por. Weber, ppor. Seńkowski i kpt. Corsi ${ }^{125}$.

Podstawę działań dywizjonu 18 sierpnia stanowiło przekazywanie meldunków 12 i 13 DP, a także rozpoznawanie sytuacji pomiędzy polskimi 6 Armią i 3 Armią, względnie Armią Czynną ${ }^{126}$. Tego dnia Dywizjon zauważył nie tylko kawalerię, ale także piechotę w marszu na zachód do Rozdołu ${ }^{127}$. Od lotników oczekiwano też ustalania pozycji jednostek Wojska Polskiego. Dzięki meldunkowi lotniczemu sztab 6 Armii dowiedział się, że 12 DP walczyła z nieprzyjacielem na zachód od Zborowa i pod jego naciskiem odchodziła na południowy zachód ${ }^{128}$.

Pomiędzy Lwowem a 1 Armią Konną stały stosunkowo skromne siły ze składu 6 DP. W Sieciechowie znajdowała się bateria artylerii i dwa czołgi, w Czartowskiej Skale i Podborcach po jednej kompanii piechoty, w Dublanach - kompania sztabowa, w Kamienopolu dowództwo 54 pp i bateria szkolna, w Grzybowicach Wielkich kompania saperów, a w Laszkach (jako rezerwa) szwadron 6 Pułku Ułanów. W rejonie Czartowska Skała-Kamienopol-Grzybowice Wielkie miały się też skoncentrować 240 i $20 \mathrm{pp}^{129}$. Pewne nadzieje można było wiązać z poaustriackimi umocnieniami Lwowa i znajdującymi się tam bateriami artylerii. W samym Lwowie było 13 baterii, wyposażonych $\mathrm{w}$ działa rosyjskie, austriackie i francuskie ${ }^{130}$.

Właśnie 18 sierpnia siły broniące Lwowa zostały wydatnie wzmocnione przez brygady ze składu 13 DP. Rankiem XXV Brygada Piechoty (BP) wyprzedziła południową flankę 1 Armii Konnej i zajęła pozycje obronne na wysokości Biłki Szlacheckiej. Tam nawiązała styczność z załogą Lwowa. Uporczywą obroną uniemożliwiła Budionnemu wyjście na szosę Winniki-Lwów, skąd miałby otwartą drogę do Lwowa ${ }^{131}$. W czasie walk nadeszła od strony Kurowic druga z brygad dywizji - XXVI BP - i atakiem na tyły

\footnotetext{
${ }^{124}$ Ibidem.

${ }^{125}$ K. A. Tarkowski, Lotnictwo polskie..., s. 103-104.

${ }^{126}$ W. Madejski, Lotnictwo w bitwie..., s. 477. Zob. też: IV Eskadra Wielkopolska..., s. 112.

${ }^{127}$ W. Madejski, Lotnictwo w bitwie..., s. 478.

${ }^{128}$ Meldunek sytuacyjny Dowództwa Okręgu Generalnego Lwów z 19 sierpnia 1920 r. [w:] Bitwa lwowska..., cz. II, s. 608.

${ }^{129}$ Meldunek sytuacyjny wieczorny dowództwa 6. Armii z 18 sierpnia 1920 r. [w:] ibidem, s. $548-549$.

${ }^{130}$ Plan umocnień Lwowa oraz rozmieszczenie artylerii z 18 sierpnia 1920 r. [w:] ibidem, s. 551 .

${ }^{131}$ J. Stawiński, Likwidacja ostatniego zagonu Budiennego, „Przegląd Kawaleryjski” 1930, nr 10, s. 188.
} 
rozbiła $6 \mathrm{DK}$, uchodzącego przeciwnika wpędziła w bagna i zadała mu znaczne straty w ludziach, koniach i sprzęcie wojskowym ${ }^{132}$.

Pewne niebezpieczeństwo groziło stolicy Galicji jeszcze ze strony północno-wschodniej. Czerwonoarmistom udało się bowiem zająć Sulimów, oddalony od Lwowa o ok. $20 \mathrm{~km}$. Zadanie zniszczenia przeciwnika w tej miejscowości otrzymała 1 DJ płk. Rómmla. Z Rómmlem miały współpracować I BJ i podwieziony na wozach konnych batalion piechoty z Kulikowa. Zakładano atak Rómmla z północy i zepchnięcie nieprzyjaciela na brygadę stojącą w Udnowie oraz na 6 DP, która stała na linii Dublany-Żydatycze ${ }^{133}$.

Położenie nadal uznawano za tak groźne, że III DL wycofano na lotniska pod Przemyślem: Hureczko, Radymno, Medykę i Muninę. Na potrzeby Dywizjonu opróżniono między innymi budynki zajmowane przez oborę koncentracyjną i rzeźnię 6 Armii. Na lotnisku Lewandówka we Lwowie pozostało tylko dowództwo dywizjonu i grupa mechaników ze sprzętem niezbędnym do obsługi samolotów. Rankiem samoloty miały przelatywać z Przemyśla do Lwowa i stamtąd realizować loty ${ }^{134}$.

Dla wykonywania zadań w dniu 19 sierpnia dowództwo Frontu Południowego przekazało dwa samoloty sztabowi 6 Armii. Pierwsza załoga miała wykonać rozpoznanie bliższe, wzdłuż trasy: Lwów-Reichenbach (pod Krasowem)-Brodki (na północ od Mikołajowa)-Bóbrka-Przemyślany-Żółtańce-Dzibułki i przez Żółkiew powrócić do Lwowa. Dla drugiego samolotu przewidziano lot bardziej w głąb, wzdłuż trasy Lwów-Narajów-BrzeżanyPomorzany-Złoczów-Krasne-Busk-Nowy Jaryczów-Lwów ${ }^{135}$.

Tej samej nocy, gdy wydawano rozkazy III DL, na podejściach do Lwowa skoncentrowano poważniejsze siły 13, 6 i 5 DP. Piechota zaryglowała Budionnemu drogę do Lwowa. 1 Armia Konna nie miała sił, by przebić się przez tę rubież $\dot{z}^{136}$. Wróg nadal stał pod Lwowem, ale już rankiem 19 sierpnia 1 DJ płk. Rómmla rozpoczęła przeciwnatarcie. Zbliżała się też 12 DP. Strona polska odczytała ponadto radiodepeszę, nakazującą Budionnemu skoncentrować się w rejonie Uściług-Włodzimierz Wołyński i uderzyć na tyły polskiej $3 \mathrm{Armii}^{137}$. Wkrótce lotnicy potwierdzili odejście Budionnego sprzed frontu

\footnotetext{
${ }^{132}$ Meldunek sytuacyjny Dowództwa Okręgu Generalnego Lwów z 19 sierpnia [w:] Bitwa lwowska..., cz. II, s. 608.

${ }^{133}$ Rozkaz operacyjny nr 4 dowództwa 6. Armii z 18 sierpnia 1920 r. [w:] ibidem, s. 550.

${ }^{134}$ E. Lewandowski, Zarys historji..., s. 379-380. Zob. też: IV Eskadra Wielkopolska..., s. 114; E. Lewandowski, Lotnictwo $w$ walce..., s. 32; W. Madejski, Lotnictwo w bitwie..., s. 475.

${ }^{135}$ Rozkaz do dowództwa Grupy Lotniczej z 18 sierpnia 1920 r. [w:] Bitwa lwowska..., cz. II, s. 548 .

${ }^{136}$ L. Wyszczelski, Wojna polsko-rosyjska..., s. 372.

${ }^{137}$ Rozkaz operacyjny nr 8 dowództwa Frontu Południowego z 19 sierpnia 1920 r. oraz Rozkaz operacyjny nr 9 dowództwa Frontu Południowego z 19 sierpnia 1920 r. [w:] Bitwa lwowska..., cz. II, s. 574-576, 578. Zob. też: W. Madejski, Lotnictwo w bitwie..., s. 478.
} 
6 Armii w kierunku północno-wschodnim. Oddziały nieprzyjacielskie nadal gromadziły się jednak na wschód od Lwowa. Jednostki Frontu Południowo-Zachodniego obsadziły linię obronną Żółtańce-Kłodno-Barszczowice-Biłka Królewska ${ }^{138}$. Meldunki lotnicze mówiły także o marszu 400 jeźdźców z Remontowic na Żółtańce i 1 tys. z Barszczowic do lasu na północ od Pikułowic ${ }^{139}$.

Front Południowo-Zachodni Aleksandra Jegorowa kierował się w tych dniach także na południe od Lwowa. Grupa Jony Jakira zbliżała się do zagłębia naftowego i odcinała Polskę od Rumunii. Nie miała trudnego zadania, bowiem polska obrona na tym obszarze była tylko symboliczna. Jedna z załóg III DL wykryła w Mikołajowie nad Dniestrem 2 tys. nieprzyjacielskich jeźdźców ${ }^{140}$. Była to część 8 DK, maszerującej na trasie Borynicze-Brzozdowce-Rozdół-Mikołajów i kierującej się na Komarno ${ }^{141}$. Kolejny oddział ze składu dywizji szedł jeszcze bardziej na południe przez Żydaczów na Stryj ${ }^{142}$. Następną wielką jednostkę kawalerii polskie lotnictwo zaobserwowało zdecydowanie bliżej Lwowa. W marszu z Dźwinogrodu do Szołomyi znajdowała się licząca około 500 ludzi brygada kombriga Grigorija Kotowskiego, także z Grupy Jakira ${ }^{143}$.

Na podstawie meldunków lotniczych na następny dzień zaplanowano już tylko wiązanie Budionnego za pomocą 1 DJ i zniszczenie Grupy Jakira przez 6 Armię oraz 12 DP. Siły polskie spod Lwowa zobligowano do przeprowadzenia energicznego kontruderzenia. Znów dwa samoloty zostały oddane na wyłączny użytek dowódcy 6 Armii. Ponadto III DL miał zapewnić łączność ${ }^{144}$. Tegoż 19 sierpnia do sztabu Frontu Południowego dotarła wieść

${ }^{138}$ CAW-WBH, Szef. Lot. NDWP, sygn. I.301.12.26, Działalność III Dywizjonu Lotniczego za miesiąc sierpień 1920 r. z 1 października 1920 r., b.m., b.p.

${ }^{139}$ W. Madejski, Lotnictwo w bitwie..., s. 479. Zob. też: IV Eskadra Wielkopolska..., s. 114-115.

${ }^{140}$ Meldunek do Dowództwa Okręgu Generalnego we Lwowie złożony na ręce Szefa Sztabu Generalnego z 19 sierpnia 1920 r. [w:] Bitwa lwowska..., cz. II, s. 608.

${ }^{141}$ Rozkaz operacyjny nr 8 dowództwa Frontu Poludniowego oraz Rozkaz operacyjny nr 9 dowództwa Frontu Południowego [w:] ibidem, s. 574-576, 578. Zob. też: IV Eskadra Wielkopolska..., s. 114-115; W. Madejski, Lotnictwo w bitwie..., s. 478-479.

${ }^{142}$ CAW-WBH, Szef. Lot. NDWP, sygn. I.301.12.26, Działalność III Dywizjonu Lotniczego za miesiąc sierpień 1920 r. z 1 października 1920 r., b.m., b.p.

${ }^{143}$ Rozkaz operacyjny $n r 8$ dowództwa Frontu Południowego oraz Rozkaz operacyjny nr 9 dowództwa Frontu Poludniowego [w:] Bitwa lwowska..., cz. II, s. 574-576, 578. Zob. też: IV Eskadra Wielkopolska..., s. 114-115; W. Madejski, Lotnictwo w bitwie..., s. 478-479.

${ }^{144}$ CAW-WBH, Szef. Lot. NDWP, sygn. I.301.12.26, Działalność III Dywizjonu Lotniczego za miesiąc sierpień 1920 r. z 1 października 1920 r., b.m., b.p.; a także Rozkaz operacyjny nr 8 dowództwa Frontu Południowego oraz Rozkaz operacyjny nr 9 dowództwa Frontu Południowego [w:] Bitwa lwowska..., cz. II, s. 574-576, 578. Zob. też: W. Madejski, Lotnictwo w bitwie..., s. 478. 
o zwycięstwie pod Warszawą. Za pomocą samolotów przekazano ją do podległych wielkich jednostek ${ }^{145}$.

Także w dniu 19 sierpnia lotnicy mjr. Faunt le Roy atakowali nieprzyjacielską kawalerię, ale na dużo mniejszą skalę niż wcześniej. Zrzucono ledwie niecałe $170 \mathrm{~kg}$ bomb i wystrzelono 1,4 tys. pocisków. W sumie III DL przeprowadził 19 sierpnia 17 lotów bojowych ${ }^{146}$. Po cztery zadania w powietrzu wykonali por. pil. Dziembowski i por. pil. Hendricks. Pierwsze ich loty zaczęły się o godz. 8:00, a ostatnie trwały do 20:00 ${ }^{147}$. Prowadzone w tym czasie przez pilotów myśliwskich akcje miały związek z bojami własnej kawalerii pod Żółtańcami i Zwertowem ${ }^{148}$.

Kolejne cztery zadania zrealizowała załoga $5 \mathrm{EW}$ - por. pil. Kalkus i ppor. obs. Turbiak. Ponadto loty były udziałem: sierż. pil. Solskiego i ppor. obs. Janiszewskiego oraz ppor. pil. Nazimka i ppor. obs. Brauna ${ }^{149}$.

Prawdopodobnie to 19 sierpnia został zestrzelony samolot por. obs. Franciszka Pinińskiego z 6 EW. Po awaryjnym lądowaniu obserwator wspierał ogniem pokładowej broni maszynowej polską kawalerię pod Żółtańcami, o którą to miejscowość toczono wówczas walki ${ }^{150}$.

${ }^{145}$ W. Madejski, Lotnictwo w bitwie..., s. 479. Zob. też IV Eskadra Wielkopolska..., s. 114-115. Juliusz Rómmel zapamiętał ten moment w następujący sposób: „Prawie w tejże chwili, przerywając moje błogie rozmyślanie, tuż przed naszem wzgórzem nagle wylądował polski samolot. Przy lądowaniu, które odbyło się na zbyt mokrej łące, aparat stanął dęba ogonem ku górze i przewrócił się. Chwila oczekiwania, przerażenia, czy lotnik żyje. Patrzymy $\mathrm{z}$ uwagą przed siebie. Jeszcze mały moment i oto z pod [sic!] aparatu wyskakuje dzielny lotnik, biegnie w naszym kierunku, wymachując ku nam jakąś depeszą. Była to, jak się okazało, depesza z Armji. Odbieram. Czytam. W pierwszej chwili nie rozumiem nic. Jakaś ciemna zasłona spada mi na oczy. Znów jaśniej. Jeszcze nie mogę pojąć. Litery i cyfry skaczą mi przed oczyma w fantastyczny sposób. Nareszcie rozumiem! Rozumiem raczej intuicyjnie, wzrokowo jeszcze nie opanowałem całkowicie otrzymanej depeszy. Już wiem! Stało się coś tak niezwykłego, tak radosnego! Czegoś tak przyjemnego nie słyszeliśmy od dawna. Fala szczęśliwości zalewa mi mózg i serce. Słyszę radosny głos lotnika po raz już chyba setny powtarzającego zgromadzonym wokół oficerom, że Warszawa uratowana! Bolszewicy pobici na głowę nad Wisłą. Cała ich armja ucieka w najwyższym popłochu. Tysiące jeńców, setki armat, dostały się jako zdobycz w nasze ręce", J. Rómmel, Wspomnienia z bojów kawalerii, Warszawa 1934, s. 73-74.

${ }^{146}$ CAW-WBH, Szef. Lot. NDWP, sygn. I.301.12.26, Działalność III Dywizjonu Lotniczego za miesiąc sierpień 1920 r. z 1 października 1920 r., b.m., b.p.

${ }^{147}$ W. Madejski, Lotnictwo w bitwie..., s. 479. Zob. też IV Eskadra Wielkopolska..., s. 114-115.

${ }^{148}$ T. Turbiak, Walki III Dywizjonu..., s. 130.

${ }^{149}$ CAW-WBH, Szef. Lot. NDWP, sygn. I.301.12.26, Działalność III Dywizjonu Lotniczego za miesiąc sierpień 1920 r. z 1 października 1920 r., b.m., b.p.

${ }^{150}$ Krzysztof Tarkowski datował zestrzelenie por. Pinińskiego na 23 sierpnia (zob. idem Lotnictwo polskie..., s. 104). Do tego czasu oddziały Armii Czerwonej zostały jednak odrzucone. Ponadto $\mathrm{w}$ wykazach lotów $\mathrm{z}$ tego dnia próżno szukać $6 \mathrm{EW}$. 
W nocy z 19 na 20 sierpnia Budionny przerwał atak, wycofał się, a po kilku dniach, wspierany przez dwie dywizje strzeleckie, rozpoczął marsz na Lubelszczyznę. Jego celem miało być teraz uratowanie Frontu Zachodniego Tuchaczewskiego. Kolumny 1 Armii Konnej skierowały się na Bełz i Sokal ${ }^{151}$.

\section{Podsumowanie}

Walki pod Lwowem skończyły się niepowodzeniem 1 Armii Konnej. Polacy uratowali stolicę Galicji. Niebagatelną rolę odegrało lotnictwo, o czym świadczył szereg rozkazów pochwalnych, a także słynna przechwycona radiodepesza Budionnego ${ }^{152}$. Pomiędzy 9 a 19 sierpnia dywizjon zrealizował ponad 250 zadań w powietrzu. W tym czasie polscy lotnicy wystrzelili niemal 33 tys. pocisków i zrzucili prawie $10 \mathrm{t}$ bomb.

Za akcje u bram Lwowa chwalony był cały Dywizjon. Pewną grupę lotników wyróżniono jednak szczególnie. Ordery Virtuti Militari V kl. za loty w tym czasie otrzymali: por. pil. Kalkus, por. obs. Paleolog i obs. Turbiak z 5 EW; por. obs. Piniński, sierż. pil. Rączka i plut. pil. Tissler z 6 EW; a także por. pil. Dziembowski, por. pil. Hendricks i ppor. pil. Lewandowski z 15 EM. Męstwo w walce z Konarmią było elementem wniosków o odznaczenie Virtuti Militari także w przypadku: por. obs. Janiszewskiego, ppor. obs. Brauna, por. obs. Popiela-Sulimy, por. pil. B. Lepszego i sierż. pil. Ryby z 5 EW; a także ppor. obs. Ryszarda Hesse i por. obs. Fabiana z 6 EW. Niezależnie od odznaczeń słowa uznania wyrażono wobec: por. pil. Kalkusa, por. obs. Popiela-Sulimy, ppor. obs. Turbiaka, ppor. obs. Paleologa, sierż. pil. Ryby, sierż. pil. Solskiego z 5 EW; por. pil. Wiesiołowskiego, por. obs. Pinińskiego, sierż. pil. Rączki, plut. pil. Tisslera i ppor. obs. Tarasiewicza z 6 EW; por. pil. Dziembowskiego i ppor. pil. Lewandowskiego z 15 EM; a także kpt. pil. Corsiego

${ }^{151}$ J. Stawiński, Likwidacja ostatniego..., s. 189. Zob. też: H. Mordawski, Polskie lotnictwo..., s. 320-321. Lech Wyszczelski stwierdził, że Budionny przerwał atak dopiero 20 sierpnia po południu; zob. idem, Lwów $1920 \ldots$, s. 209.

152 „W ostatnich dniach nieprzyjaciel w szerokim zakresie zastosował w walce z kawalerją [sic!] samoloty, w ten sposób kompensując zbyt szczupłe siły. W dniu 16 i 17 sierpnia eskadry nieprzyjaciela w liczbie dochodzącej do 9 samol. krążyły nad nacierającymi kolumnami konnej armji [sic!]. Zuchwale zniżając samoloty, nieprzyjaciel ostrzeliwał nasze oddziały i zarzucał je bombami. Wojska atakowane z powietrza nie mniej, niż trzy razy na dzień, mają ogromne straty w ludziach i koniach. W jednej tylko 6 dywizji kawalerji w dn. 17.VIII zabito i raniono przeszło 100 ludzi i 100 koni. Jedno z natarć 6-ej dywizji kaw., odparto wyłącznie zapomocą [sic!] samolotów. Proszę o rozkaz natychmiastowego wysłania do mego rozporządzenia jednej baterji [sic!] przeciwlotniczej, któraby [sic!] podążała za armją”. CAW-WBH, Szef. Lot. NDWP, sygn. I.301.12.26, Radiodepesza Budionnego przechwycona 18 sierpnia 1920 r. przez polski radiowywiad, 1 września 1920 r., b.m., b.p. 


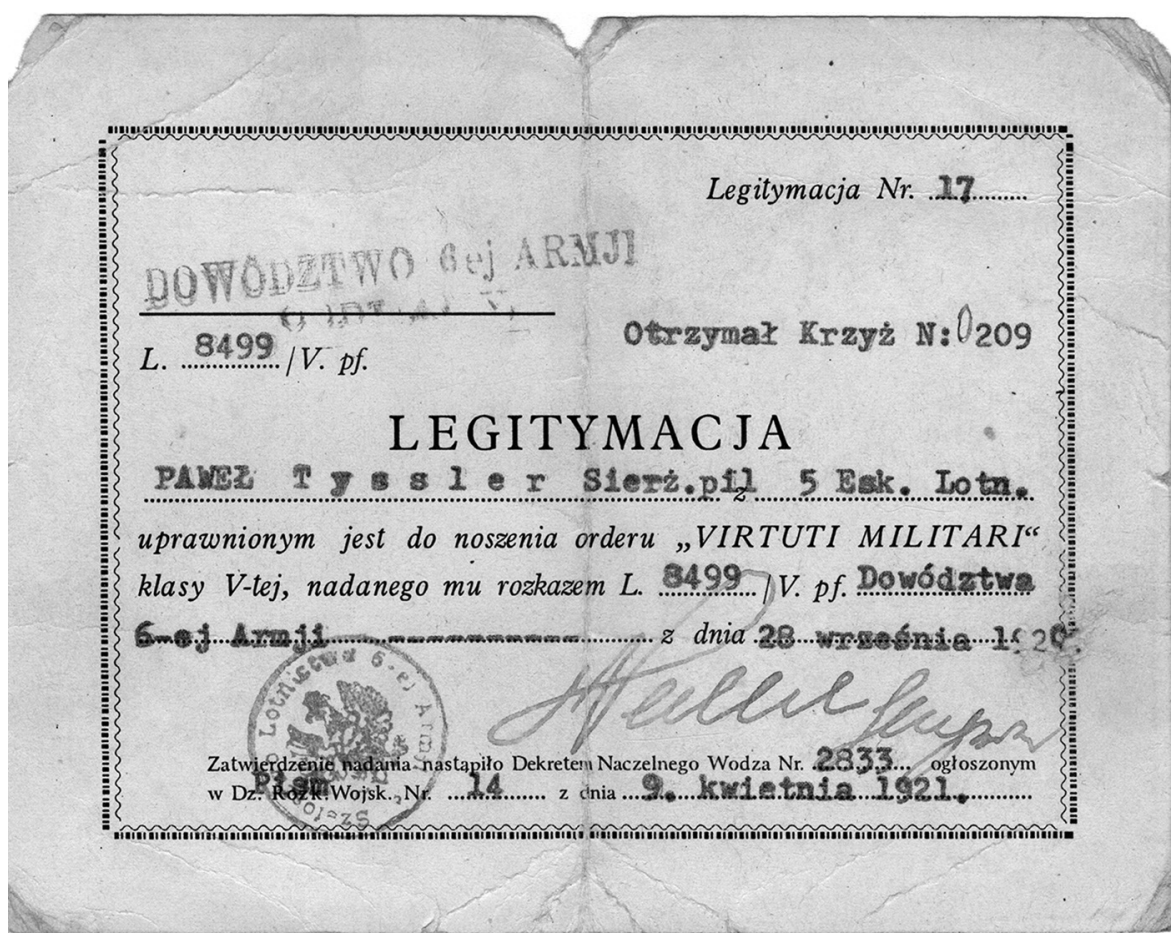

Fot. 5. Legitymacja Krzyża Srebrnego Orderu Wojskowego Virtuti Militari plut. pil. Pawła Tisslera. Zwraca uwagę sposób zapisu nazwiska zasłużonego lotnika - „Tyssler”. W dokumentach i literaturze można napotkać też formę „Tysler”. W czasie bitwy o Lwów Tissler przynależał do personelu 6 Eskadry Wywiadowczej

Źródło: zdjęcie ze zbiorów Muzeum Lotnictwa Polskiego w Krakowie

i por. pil. Webera z 7 EM. Pochwały spłynęły ponadto pod adresem dowódcy dywizjonu mjr. Faunt le Roy oraz oficera taktycznego por. obs. Kubali ${ }^{153}$.

Doświadczenia $\mathrm{z}$ walk samolotów przeciw kawalerii u bram Lwowa znacząco wpłynęły na polską koncepcję wykorzystania lotnictwa. Już wkrótce po zakończeniu wojny $\mathrm{z}$ bolszewicką Rosją postulowano utworzenie eskadr przeznaczonych specjalnie do zwalczania kawalerii. Możliwość rzucenia samolotów (w tym jednomiejscowych myśliwców) do spowolnienia jednostek kawaleryjskich przewijała się przez polskie prace teoretyczno-lotnicze tak w latach dwudziestych, jak i trzydziestych XX w. W tej atmosferze dojrzewało kolejne pokolenie polskich lotników i nie można wykluczyć, że tę koncepcję byli oni gotowi realizować także podczas kolejnej wojny.

${ }^{153}$ Z biogramami kawalerów Orderu Wojskowego Virtuti Militari w gronie lotników Czytelnik może zapoznać się w pracy: J. Zieliński, W. Wójcik, Lotnicy Kawalerowie... 


\section{Bibliografia}

\section{Archiwalia}

Centralne Archiwum Wojskowe Wojskowego Biura Historycznego

Dowództwo Lotnictwa Ministerstwa Spraw Wojskowych

Szefostwo Lotnictwa Naczelnego Dowództwa Wojska Polskiego

\section{Źródła drukowane}

Bitwa lwowska i zamojska 25 VII-18 X 1920, oprac. zesp. pod kier. M. Tarczyńskiego, cz. I: 25 VII-5 VIII, Warszawa 2002; cz. II: 6-20 VIII, Warszawa 2004.

\section{Wspomnienia}

Lewandowski E., Lotnictwo $w$ walce $z$ armją konna Budiennego, „Przegląd Lotniczy" 1932, nr 1-2.

Lewandowski E., Zarys historji 15-ej eskadry myśliwskiej (obecnie 132-ej), „Przegląd Lotniczy" 1929, nr 5.

Rómmel J., Wspomnienia z bojów kawalerii, Warszawa 1934.

Turbiak T., Walki III Dywizjonu Lotniczego z konna armja Budiennego pod Lwowem. Wspomnienia i uwagi, „Bellona” 1922, t. V nr 2.

Mapy

Mapa Polski i krajów ościennych. Warszawa-Lwów, 1943, stan na 1 IX 1939, 1:1 000 000, http:/maps.mapywig.org/m//WIG_maps/series/M1/MPIKO_1M_ Arkusz_SE_WARSZAWA-LWOW_1943_600dpi.jpg (dostęp 4 II 2019).

Mapa taktyczna Polski, 1:100 000, 1921, Lwów, http://igrek.amzp.pl/details. php?id=10059 (dostęp 5 IV 2020).

Mapa taktyczna Polski, 1:100 000, 1922, Busk, Krasne, http://igrek.amzp.pl/details. php?id=10061 (dostęp 5 IV 2020).

Mapa taktyczna Polski, 1:100 000, 1922, Żółkiew, http://igrek.amzp.pl/details. php?id=1756338 (dostęp 5 IV 2020).

Mapa taktyczna Polski, 1:100 000, 1926, Kamionka Strumiłowa, http://igrek.amzp. pl/details.php?id=3831 (dostęp 5 IV 2020).

\section{Opracowania}

2. Pułk Lotniczy. 1919-1929, praca zbiorowa, Kraków 1929.

IV Eskadra Wielkopolska (15. Eskadra Myśliwska). 25 V 1919-29 VIII 1921, praca zbiorowa pod red. ks. R. Kulczyńskiego SDB, Warszawa 2018.

Cybulski T., Lotnictwo w operacji warszawskiej. W dziesięciolecie zwycięstwa nad Wisła, „Przegląd Lotniczy” 1930, nr 7-8.

Karolevitz R. F., Fenn R. S., Dług honorowy. Amerykańscy piloci Eskadry Myśliwskiej im. Kościuszki w wojnie polsko-bolszewickiej 1919-1920, Warszawa 2005.

Кондратьев В., Хайрулин М., Авиация гражданской войны, Москва 2000.

Kopański T. J., 7 Eskadra Myśliwska im. Tadeusza Kościuszki 1918-1921, Warszawa 2011.

Kopański T. J., Fokker DVII BI-BA-BO, „Lotnictwo z Szachownicą” 2002, nr 1. 
Kopański T. J., Samoloty brytyjskie w lotnictwie polskim 1918-1930, Warszawa 2001. Księga Pamiątkowa 3-go Pułku Lotniczego 1918-1928, Poznań 1928.

Ku czci poległych lotników. Księga pamiątkowa, pod red. M. Romeyki, Warszawa 1933.

Lewandowski E., Garść wspomnień z walk dawnej 15. myśliwskiej eskadry lotniczej (Obecnie 132) [w:] Księga Pamiątkowa 3-go Pułku Lotniczego 1918-1928, Poznań 1928.

Łydżba Ł., Fokkery w obronie Lwowa, „Lotnictwo z Szachownicą” 2009, nr 1.

Madejski W., Lotnictwo w bitwie pod Lwowem w sierpniu 1920 roku, „Przegląd Lotniczy" 1937, nr 4.

Mordawski H., Polskie lotnictwo wojskowe 1918-1920. Narodziny i walka, Wrocław 2009.

Morgała A., Samoloty wojskowe w Polsce 1918-1924, Warszawa 1997.

Niestrawski M., Polskie Wojska Lotnicze w okresie walk o granice państwa polskiego 1918-1921, t. II: Walka i demobilizacja, Oświęcim 2017.

Olejko A., Działania lotnicze w pasie karpackim w latach 1914-1947, Rzeszów 2005.

Smoliński A., 1 Armia Konna podczas walk na polskim teatrze działań wojennych w 1920 roku. Organizacja, uzbrojenie, wyposażenie oraz wartość bojowa, Toruń 2008.

Smoliński A., Udział lotnictwa Wojska Polskiego w walce z I Armia Konna podczas kampanii 1920 r., „Przegląd Historyczno-Wojskowy” 2007, nr 1 (216).

Stawiński J., Likwidacja ostatniego zagonu Budiennego, „Przegląd Kawaleryjski” 1930, nr 10.

Tarkowski K. A., Lotnictwo polskie w wojnie z Rosja Sowiecka 1919-1920, Warszawa 1991.

Wyszczelski L., Lwów 1920, Warszawa 2014.

Wyszczelski L., Wojna polsko-rosyjska 1919-1920, cz. II, Warszawa 2010.

Zieliński J., Wójcik W., Lotnicy Kawalerowie Orderu Wojennego Virtuti Militari, Warszawa-Toruń 2005.

\section{Źródła internetowe}

Tym J. S., Obrona Lwowa w sierpniu 1920 roku, https://www.ipsb.nina.gov.pl/a/ artykul/obrona-lwowa-w-sierpniu-1920-roku (dostęp 5 IV 2020).

\section{STRESZCZENIE}

\section{Mariusz Niestrawski, III Dywizjon Lotniczy w walce z 1 Armią Konną na przedpolach Lwowa (9-19 sierpnia 1920 roku)}

W sierpniu 1920 r. doszło do przełomowych operacji wojny polsko-bolszewickiej. Nad Wkrą, Wisłą i Wieprzem rozegrała się bitwa, która doprowadziła do odrzucenia wojsk Frontu Zachodniego komandarma Michaiła Tuchaczewskiego spod Warszawy i rozbicia części jego sił. W tym samym miesiącu na południowym odcinku frontu Wojsko Polskie obroniło Lwów przed zakusami komandarmów Aleksandra Jegorowa i Siemiona Budionnego. 
W walkach o Lwów doszło do starcia wojsk polskich z siłami Frontu Południowo-Zachodniego, w tym z owianą legendą 1 Armią Konną, która była główną siłą bolszewików chcących opanować stolicę Galicji. Polskie dowództwo, nie dysponując odwodami, do walki z „Konarmią” skierowało III Dywizjon Lotniczy mjr. pil. Cedrica Faunt le Roy, który mimo siły wynoszącej w apogeum nawet cztery eskadry (5 i 6 Eskadra Wywiadowcza, 7 Eskadra Myśliwska, a z czasem także 15 Eskadra Myśliwska), w praktyce w dn. 9-19 sierpnia dysponował ledwie kilkunastoma sprawnymi samolotami. Mimo tego załogi polskich maszyn wykonywały w tym czasie niestrudzenie zadania: rozpoznania sił przeciwnika - ich intencji i składu oraz, co najistotniejsze, opóźniania jego marszu.

W artykule niniejszym autor opisał skład, zadania, przebieg walk III Dywizjonu Lotniczego w starciu z 1 Armią Konną w dn. 9-19 sierpnia 1920 r. Zwrócił również uwagę na taktykę walki polskich lotników, którą poddał stosownej analizie.

Słowa kluczowe: III Dywizjon Lotniczy, 1 Armia Konna, wojna polsko-bolszewicka, eskadra wywiadowcza, eskadra myśliwska

\section{SUMMARY}

\section{Mariusz Niestrawski, 3rd Air Squadron in the Fight against 1st Cavalry Army on the Foreground of Lwów (9-19 August 1920)}

In August 1920 the turning-point operations of the Polish-Soviet war took place. A battle was fought at the Wkra, Vistula and Wieprz rivers, which led to pushing back the Western Front troops of komandarm Mikhail Tukhachevsky from Warsaw and breaking up of part of his forces. The same month, in the southern section of the front, the Polish Army defended Lviv against the attempts of komandarms Alexander Yegorov and Semyon Budyonny.

In the fights for Lviv, the Polish troops confronted the forces of the South-Western Front, including the legendary 1st Cavalry Army, which was the main force of the Bolsheviks intending to conquer the capital of Galicia. The Polish command, having no reserves at its disposal, directed the 3rd Air Squadron of Major Pilot Cedric Faunt le Roy to fight against the „Horsearmy”. Despite the strength of even four escadrilles at its peak (5th and 6th Reconnaissance Escadrilles, 7th Fighter Escadrille and, with time, 15th Fighter Escadrille), between 9-19 August it had in fact only a few operational planes. In spite of this, the Polish crews were tirelessly performing their tasks: reconnoitering enemy forces - their intentions and composition - and, most importantly, delaying their march.

In this article the author describes the composition and tasks of the 3rd Air Squadron, and the course of its fights against the 1st Cavalry Army in August 9-19, 1920. He also drew attention to the combat tactics of Polish aviators, which he analyzed accordingly.

Keywords: 3rd Air Squadron, 1st Cavalry Army, Polish-Soviet War, Reconnaissance Escadrille, Fighter Escadrille 


\section{АННОТАЦИЯ}

\section{Мариуш Нестравский. III авиаэскадрилья в боях против 1-й Конной армии на окраинах Львова (9-19 августа 1920 г.)}

В августе 1920 года состоялись переломные операции польско-большевистской войны. На Вкре, Висле и Вепше произошел бой, приведший к отбрасыванию войск Западного фронта под командованием Михаила Тухачевского из окрестностей Варшавы и разгрому части его войск. В том же месяце на южном участке фронта Войско Польское защищало Львов от попыток атаки командиров армии Александра Егорова и Семена Буденного.

В боях за Львов польские войска столкнулись с силами Юго-Западного фронта, в том числе с легендарной 1-й Конной армией, которая была главной силой большевиков, стремившихся овладеть столицей Галиции. Польское командование, не имея резервных средств, на битву с Конармией отправило 3-ю авиационную эскадрилью майора Седрика Фаунта ле Ройя, который, имея в своем распоряжении четыре эскадрильи (5-ю и 6-ю разведывательные эскадрильи, 7-ю истребительную эскадрилью, а со временем и 15-ю истребительную эскадрилью), в действительности 9-19 августа располагал всего десятком исправных самолетов. Несмотря на это, польские экипажи в то время неустанно действовали: распознавали силы противника, их намерения и состав, а главное-тормозили его продвижение.

В данной статье автор описывает состав, задачи и ход боев 3-й авиаэскадрильи против 1-й Конной армии 9-19 августа 1920 г. Также он обратил внимание на боевую тактику польских летчиков, которую подверг соответствующему анализу.

Ключевые слова: III авиационная эскадрилья, 1-я конная армия, польско-большевистская война, разведывательная эскадрилья, истребительная эскадрилья 